Portland State University

PDXScholar

\title{
A Free-Market Response to the Elementary and Secondary Education Act: The Segregationist Background and Failed Experimentation of Education Vouchers in the 1970s
}

Simon Robins

Portland State University

Follow this and additional works at: https://pdxscholar.library.pdx.edu/honorstheses Let us know how access to this document benefits you.

\section{Recommended Citation}

Robins, Simon, "A Free-Market Response to the Elementary and Secondary Education Act: The Segregationist Background and Failed Experimentation of Education Vouchers in the 1970s" (2014). University Honors Theses. Paper 83.

https://doi.org/10.15760/honors.41

This Thesis is brought to you for free and open access. It has been accepted for inclusion in University Honors Theses by an authorized administrator of PDXScholar. Please contact us if we can make this document more accessible: pdxscholar@pdx.edu. 
A Free-Market Response to the Elementary and Secondary Education Act:

The Segregationist Background and Failed Experimentation of Education Vouchers in the 1970s

by

Simon Robins

An undergraduate honors thesis submitted in partial fulfillment of the

requirements for the degree of

Bachelor of Arts

in

University Honors

and

History

Thesis Advisers

Dr. David Horowitz and Dr. David Johnson

Portland State University

2014 


\section{TABLE OF CONTENTS}

$\begin{array}{ll}\text { Chapter I: Introduction } & 3\end{array}$

Chapter II: The Tuition Grant Experiment in Prince Edward County, Virginia 7

Chapter III: National Attention - The Emerging Voucher Ideologies of Blum and Friedman 20

Chapter IV: Intervention and the Emergence of the Voucher Concept at the Federal Level 25

Chapter V: Low Scores at Alum Rock

Chapter VI: New Hampshire and East Hartford 46

Chapter VII: Conclusion - Milwaukee, Wisconsin $\quad 62$

$\begin{array}{ll}\text { Bibliography } & 68\end{array}$ 


\section{Chapter I: Introduction}

The fact is that you have got to improve the schools where the kids are. No matter how you slice it, you are not all of a sudden going to close all the poor schools in America and then transfer them someplace else to another school that is a better school than the one they were in. . I I would like to see everybody have the right to go wherever they please, but it ain't going to do any good just to provide a limited opportunity for a few people to do this and ignore the school that is there in the neighborhood

-Senator Gaylord Nelson (Dem.-Wisc.) ${ }^{1}$

At a local PTA meeting in the summer of 1970, Dr. William Jefferds was told of an approach towards educational funding through the use of tuition vouchers. ${ }^{2}$ As the Superintendent of the Alum Rock School District in east San José, California, a district serving some fifteen thousand predominantly Mexican-Americans, Jefferds, unaware of vouchers until then, found the concept appealing. ${ }^{3}$ His district was significantly underfunded in comparison to nearby counterparts, and the proposed increase in federal funding through the use of vouchers presented a potential solution to his problem. Moreover, Jefferds was trying to decentralize the authority of principals and superintendents within the district—something which vouchers also accommodated by placing more power in the hands of teachers and parents.

Jefferds was involving himself in an alternative form of education funding, a form which had previously been used as a means to sustain segregation during the 1950s and early 1960s. In spite of this troubling past, however, voucher advocates had a convincing argument in the late 1960s and early 1970s. Hypothetically, through the use of vouchers, parents could not only

\footnotetext{
${ }^{1} 27$ April, 1971, in Education Vouchers, Subcommittee on Employment, Manpower and Poverty of the Committee on Labor and Public Welfare (Washington D.C., 1971), 155

${ }^{2}$ Weiler, Daniel, and Pierce Barker. 1974. A public school voucher demonstration, the first year at Alum Rock: ${ }^{3}$ Ibid., vi. prepared for the National Institute of Education. Santa Monica, Ca: Rand, 32.
} 
choose where their children went to school, but could make decisions about curriculum and school structure. Issued to parents by a governing body, the certificates would count towards a student's tuition at any school—private or public—where they wished to send their child. This form of funding placed the choice in the hands of the consumer, supposedly ensuring that schools competed for students by improving the quality of their education. Consequently, vouchers would essentially turn the public school system into a market place, where enrollment levels determined an institution's success. Both public and private schools would compete with one another for children to attend their facility.

Despite these idealistic hypotheticals, and perhaps because of public awareness of the connection to segregation, vouchers did not appeal to many school districts. At a time when the Elementary and Secondary Education Act (ESEA) of 1965 was undergoing increased scrutiny and criticism after its promises for success after large-scale federal funding efforts had fallen short, vouchers seemed like a panacea for policy makers. For the public, however, they seemed like an unnecessary change in order to receive slightly more funding. Arguably this attraction of financial support was what led Alum Rock to become the only district in the nation to participate in a federally supported voucher demonstration during the 1970s. The state of New Hampshire and the district of East Hartford, Connecticut came close in 1973-76, but ultimately decided against vouchers, again because of money. ${ }^{4}$ In both cases, they simply did not need the money, nor did they want vouchers.

Examining the way educational vouchers were advocated by the Johnson administration and later tested by the Nixon administration and Office of Economic Opportunity suggests that they were idealistic attempts to correct an apparent shortcoming in American education for both

\footnotetext{
${ }^{4}$ Donaldson, Gordon A. 1977. Education Vouchers in New Hampshire: An Attempt at Free Market Educational Reform. Newton, Mass: C.M. Leinwand Associates.
} 
administrations. They were a largely unrealized effort for the Johnson administration following the reported failures of categorical funding in urban schools, and they were a last-resort for the Nixon administration to test free-market ideologies in the realm of education, after the president had neglected to devote a significant degree of attention towards other alternatives. Additionally for Nixon, they could, at the very least, offer a sharp contradiction to the Johnson administration's Elementary and Secondary Education Act (ESEA), which by 1969 had become an insurmountable force in American public education.

Through an examination of the segregationist background to the voucher ideology in states like Virginia; the implemented experiment at Alum Rock; the proposed experiments in the state of New Hampshire and the district of East Hartford, Connecticut from 1973-1976; and, more briefly, the recent case of vouchers being used as a last resort by urban schools in Milwaukee, Wisconsin since the early 1990s, one sees why vouchers were proposed in the context of the Great Society, but also why they failed as a result of that same context. The Elementary and Secondary Education Act was a central piece of the Great Society's legislative agenda. Above all, this agenda stressed the importance of granting increased funding towards those who had been previously denied civic liberties, and in the case of the ESEA, this was very much so the case, with its insistence on compensatory funding and tight regulation to avoid exploitation. Specifically in the case of vouchers, these concepts of regulation and compensatory funding were deemed important by Great Society policy makers in that they could prevent a return to the previous context in which they were used: in the South by segregationists in retaliation of the Supreme Court's Brown v. Board of Education 1954 decision.

Proposed within this context of heightened social welfare spending and federal oversight, an apparent lack of need was present in the cases of East Hartford and New Hampshire, and to a 
lesser extent in Alum Rock. This lack of need in East Hartford and New Hampshire, I will argue, came largely as a result of the homogenous demographics and relative affluence of these areas. Arguably, this decision by the federal government to test vouchers in these districts was directly related to the history of segregation. In Alum Rock, on the other hand, financial motives were the primary reason for the experiment to make it past the planning stage. And in response to the relative poverty of this district, we see fears of exclusion and segregation driving the decisions of policy-makers in Alum Rock, where the voucher model tested was tightly regulated—much more so than the free-market models proposed in the other two cases.

Therefore, fears concerning segregation, as well as the efficacy of vouchers in relation to pre-existing education models were at the forefront of the critiques made against vouchers by federal legislators, state and city governments, and local school district populations. This paper argues that all three voucher experiments planned or implemented by the federal government during the 1970s failed as a direct result of these fears and concerns, as well as the context of the Great Society which stressed regulation and compensatory funding. 


\section{Chapter II: The Tuition Grant Experiment in Prince Edward County, Virginia}

The potential for vouchers to be used by those with oppressive political agendas-namely segregationists—can be seen in the multiple voucher programs implemented in the South before the passage of the ESEA in 1965. Ten years earlier, six southern states began discussing the value of vouchers after the U.S. Supreme Court ruled in Brown v Board of Education (1954) that segregation in public schooling was illegal. ${ }^{5}$ As a last resort to avert the onslaught of desegregation, these states issued tuition vouchers and often closed school districts to fund private, segregated academies, again supported by vouchers. ${ }^{67}$ Examining the particular case of Prince Edward County, Virginia from 1951-1969 helps elucidate the potential dangers of deregulated vouchers when handled by those with an extreme agenda. It also shows the direct link that this early use of vouchers had with the proposals made by federal policy makers starting in the late 1960s.

In 1930, the state of Virginia passed a law allowing tuition grants to be issued to children whose fathers died as a result of the First World War. ${ }^{8}$ The law covered the payment of "matriculation fees, board and room, rent and books, and supplies" for students planning to attend either secondary school or college. ${ }^{9}$ Over the next twenty -five years, this program was

\footnotetext{
${ }^{5}$ LaNoue, George R. 1972. Educational Vouchers; Concepts and Controversies. New York: Teachers College Press, 156-157.

${ }^{6}$ Daugherity, Brian J., and Charles C. Bolton. 2008. With all Deliberate Speed: Implementing Brown v. Board of Education. Fayetteville: University of Arkansas Press, vii.

${ }^{7}$ The other example of segregationists using vouchers occurred in Louisiana. For an in-depth analysis of this case, see Jim Carl's chapter in his monograph Freedom of Choice: Vouchers in American Education (Santa Barbara, Calif: Praeger, 2011). Also, vouchers being used in Roman Catholic high schools in Burlington, Vermont was deemed unconstitutional by the Supreme Court of Vermont in 1961. This occurred at several high schools from 1952-58. See Swart v. Burlington, 122 Vt. 177 (1961).

${ }^{8}$ Griffin Et Al. v. County School Board of Prince Edward County, 377 U.S. 218 (1964), footnote 1.

${ }^{9}$ Almond v. Day, 197 Va. 419, 89 S. E 2d 851 (1955), Section 854
} 
expanded to include children of Second World War victims as well. ${ }^{10}$ However, in late 1955 , the Supreme Court of Appeals of Virginia struck down the law under the pretense "that giving grants to children attending private schools violated the Virginia Constitution." 11 Specifically, they argued, it violated Section 141 of the state constitution, a section which declared that no portion of state education funds "be diverted from that purpose [in order to fund] private schools."12 This decision went unchallenged, and the program was discontinued.

However, as a result of Brown v Board of Education, the legislature amended the same section of the state constitution the following year in order to allow "the General Assembly and local governing bodies to appropriate funds to assist students to go to public or to nonsectarian private schools." ${ }^{13}$ What was initially an innocent concept to generously assist the children of deceased veterans had suddenly been adopted by segregationists as a potential way to maintain segregation.

What ensued as a result of this constitutional amendment and allocation of tuition vouchers was a public school system in Prince Edward County which remained almost entirely segregated until 1969. This coincided with the abandonment and closure of the public school system in the county from 1959 through 1965, a small jurisdiction of fourteen-thousand people

\footnotetext{
${ }^{10}$ As stated by the court case, "The 1930 Act provided for the payment of 'matriculation fees, board and room rent and books and supplies for the use and benefit of such children who were attending or might attend 'a State educational or training institution of secondary or college grade"" (Section 853). "In 1952 this section was amended to provide for the payment of such matriculation fees, board and room rent and books and supplies 'at any educational or training institution of collegiate or secondary grade in the State of Virginia approved in writing by the Superintendent of Public Instruction'. This last amendment limited the amount of such expenditures to 'such funds as shall be appropriated for the purpose in the general appropriation acts"” (Section 853). Almond v. Day, 197 Va. 419, 89 S. E 2d 851 (1955)

${ }^{11}$ Almond v. Day, section 858

${ }^{12}$ Ibid., section 855

13 "By 1957, more than one-half of southern states had repealed their constitutional requirements to maintain a school system.”-- Titus, Jill Ogline. 2011. Brown's Battleground: Students, Segregationists, and the Struggle for Justice in Prince Edward County, Virginia (Chapel Hill: University of North Carolina Press), pp. 16.
} 
in the center of the state that acted alone as the process of integration spread within its borders. ${ }^{14}$ While county schools were closed and a majority of African-American children went without education for six years, white students went to the publicly funded and privately sponsored Prince Edward Academy. This resulted in a legal battle between the National Association for the Advancement of Colored People (NAACP) and the courts that resulted in the Griffin v County School Board case (1964) that would reopen the schools in May of $1964 .{ }^{15}$ Crucially, though, the use of vouchers to maintain segregation within the re-opened public school system would continue until June of $1969 .^{16}$

Through an examination of the rise of "massive resistance," the succession of policy plans which led to the use of tuition vouchers, and the reasons presented for closing of the public schools in Prince Edward County, one can see how vouchers could be used for a political agenda unrelated to improving access to education. In the case of Prince Edward County, the objective was entirely opposite to the free market ideology later cherished by voucher advocates. Yet voucher ideologies were often advocated as a proposal for the betterment of society according to neo-liberal principles advocated by political liberals and political conservatives alike, and could prove attractive on the basis of choice regarding educational quality and source.

The eventual decision to use tuition vouchers in the Prince Edward County began with a student-led strike. Dissatisfied by a lack of maintenance of school facilities, 456 six black high school students walked out of R.R. Moton High School on April 23rd, $1951 .{ }^{17}$ Initially their aim was not to desegregate the school system, but rather to improve the quality of their schools. ${ }^{18}$

\footnotetext{
${ }^{14}$ Bonastia, Christopher, Southern Stalemate: Five Years Without Public Education in Prince Edward County, Virginia (Chicago: The University of Chicago Press, 2012), pp. 2.

${ }^{15}$ Griffin v. State Board of Education, 296 F. Supp. 1178-Dist.

16 Ibid.

${ }^{17}$ Bonastia, Stalemate, 2, 33.

${ }^{18}$ Ibid., 41.
} 
Yet, on May 3rd, attorneys from the NAACP decided that the time was right to petition and call for complete desegregation, claiming "that by enforcing section 140 of the Virginia constitution, which stipulated that white and black children be taught in separate schools, the board was denying equal educational facilities to Negroes." ${ }^{, 19}$ This petition would eventually turn into a lawsuit against the state, a lawsuit which would later become one of the five cases to constitute Brown v. Board of Education. ${ }^{20}$

As a result of Brown, Virginians had a fresh set of concerns about the operation of their public schools. More broadly, both the 1954 Brown v Board Education decision, as well as the Brown v Board of Education II from March of 1955, ${ }^{21}$ which set more specific parameters on how to desegregate, produced a knee-jerk reaction on behalf of state governments across the South. Determined to fight the implementation of integration, 101 of the 128 members of Congress from states which constituted the former Confederacy signed a "Declaration of Constitutional Principles" in March 1956, now commonly known as the "Southern Manifesto.",22 The statement declared its intent to "to use all lawful means to bring about a reversal of [the Brown] decision which is contrary to the Constitution and to prevent the use of force in its implementation." ${ }^{, 3}$ The manifesto can be seen as part of a broader initiative to sustain what Virginia Senator Harry Byrd labelled as "Massive Resistance" to the onslaught of "federal intervention" in southern politics. ${ }^{24}$ The region-wide effort was headed by Strom Thurmond of South Carolina and Harry Byrd of Virginia, two of the most powerful senators in the nation and

\footnotetext{
${ }^{19}$ Ibid., 37.

${ }^{20}$ Ibid., 2.

${ }^{21}$ Brown v. Board of Education, 349 US 294, 75 S. Ct. 753, 99 L. Ed. 1083 - Supreme Court, 1955.

${ }^{22}$ Titus, Brown's Battleground, 16.

${ }^{23}$ Bonastia, Stalemate, 68.

24 Titus, Brown's Battleground, 17.
} 
within their respective states. In Virginia, over fifty groups geared towards maintaining segregation were created in the following years. ${ }^{25}$

Serving as governor of Virginia from 1926 to 1930 and U.S. senator from 1933 through 1965, Harry Flood Byrd was considered the most powerful man in Virginia politics. ${ }^{26} \mathrm{He}$ enforced a strict, hierarchical organization—described by one historian as an "oligarchy"— which left Virginia under the control of a relatively small number of public officials, often controlled by Byrd's "legendary political machine." ${ }^{, 7}$ When this "machine" was faced with the federal mandate to desegregate state schools—in turn undoing much of its strict hierarchical and racist nature — the effort for resistance was strong.

In order to achieve the statewide goal of massive resistance, Byrd worked in accordance with Virginia governor, Thomas B. Stanley. In August 1954, roughly three months after Brown, Byrd had the governor create a commission to decide how to effectively circumvent the mandate for desegregation. ${ }^{28}$ To head the panel, Stanley appointed Garland Gray, a wealthy state Senator from Virginia's mostly African American fourth district who was notorious for his support of the Byrd machine. Given the authority to use any means available, the Gray commission received orders to outline their advice in a report. ${ }^{29}$

Before they began writing, though, the commission decided to host a public meeting at a mosque on November 15, 1954. Over two thousand people attended and over one-hundred gave speeches, most suggesting that segregation be continued. In extreme cases, speakers advocated for an "abolition or destruction of the public school system," in the case that integration was

\footnotetext{
${ }^{25}$ Ibid., 16.

${ }^{26}$ Ibid., 15.

${ }^{27}$ Ibid., 15.

${ }^{28}$ Gray, Garland, Public Education Report of the Commission to the Governor of Virginia, Commonwealth of Virginia Division of Purchase and Printing Richmond, 1955.

29 Bonastia, Southern Stalemate, 52.
} 
required by the county. ${ }^{30}$ Lastly, a third group suggested that local school districts should have the option to design their own school systems. ${ }^{31}$ These suggestions were taken into account when two interim reports were drafted over the first half of 1955, and a final draft submitted to the governor's office on November 11, 1955. ${ }^{32}$ The Report of the Commission to the Governor of Virginia expressed disbelief that the Fourteenth Amendment was now being applied to public schools. ${ }^{33}$ Further, the report suggested the following:

To meet the problem thus created by the Supreme Court, the Commission proposes a plan of assignment which will permit local school boards to assign their pupils in such manner as will best serve the welfare of their jurisdiction. The Commission further proposes legislation to provide that no child be required to attend a school wherein both white and colored children are taught and that the parents of those children who object to integrated schools, or who live in communities wherein no public schools are operated, be given tuition grants for educational purposes. ${ }^{34}$

Equally important, the commission suggested that section 141 of the Virginia

Constitution be amended to coincide with the tuition grant proposal. Lastly, it disregarded the requirement that schools remain open for the nine-month academic year. Instead, they could close if faced with an "emergency." 35 The commission hoped to achieve this before the fall term of the 1956 school year. ${ }^{36}$ Under this plan, therefore, children would either be placed by the local school board at a local school deemed appropriate, or parents would have the option to choose a school through the use of a tuition grant, especially if their children had been placed at an integrated school.

Importantly, the report did not call for the state to prohibit integration in any event. Therefore, it could be seen as a small step towards integration, albeit only where the local school

${ }^{30}$ Gray, Public Education Report, 14. Letter, January 19, 1955, from Gray to Stanley, included in report.

${ }^{31}$ Bonastia, Southern Stalemate, 52.

${ }^{32}$ Gray, Public Education Report, 5.

${ }^{33}$ Ibid, 5.

${ }^{34}$ Ibid, 8.

${ }^{35}$ Ibid, 12.

${ }^{36}$ Ibid, 8. 
board agreed with the placement of white children besides African Americans. While Governor Stanley initially supported these ideas, however, his support soon dissipated when he was persuaded by strict segregationists to oppose any plan which allowed integration, no matter the degree. ${ }^{37}$ Much of this had to do with the ideology of the strict segregationist group, the Defenders. Formed in the early 1950s in order to prohibit the "expenditure of any public monies in the maintenance and operation of any integrated public schools," the Defenders disagreed with the report over the "liberty" it granted local school boards to place pupils. Instead, they felt the placements should be done exclusively by the governor, in order to ensure that complete segregation could continue. ${ }^{38}$ The Gray plan adhered to many of the ideas of the Defenders yet differed in its failure to allow for the complete abandonment of the public schools. ${ }^{39} \mathrm{Byrd}$, too, disagreed with the Gray plan. Most alarming for the senator was Gray's allowance of students and parents to petition local courts for acceptance to a school of the opposite race when denied admission to a school of their choice. ${ }^{40}$

As a result of these disagreements between moderate and strict segregationists, Stanley publicly stated in May 1956 that he wanted to consider alternate legislative actions. ${ }^{41}$ In July, members of the Gray commission met with state representatives in Washington, D.C. to discuss what the new plan would look like. Their decision reflected their recent acceptance of strict segregationist attitudes. There was to be no integration. Those who disagreed with this were to be penalized by a forced forfeit of their state funds for education. Most importantly, the governor would now be the one who assigned the students to their schools, as opposed to local

\footnotetext{
${ }^{37}$ Bonastia, Southern Stalemate, 66.

${ }^{38}$ Ibid., 56.

${ }^{39}$ Ibid., 66.

${ }^{40}$ Ibid., 71.

${ }^{41}$ Ibid., 70.
} 
school boards. ${ }^{42}$ As was the case with the Gray plan, those who disagreed with their school assignment could request tuition grants to attend private, nonsectarian schools. ${ }^{43}{ }^{44}$ This new plan became known as the "Stanley Plan," and in August it was accepted by the Gray Commission by a vote of nineteen to twelve. ${ }^{45}$ As historian Christopher Bonastia has argued, the vote on the Stanley Plan was hardly unanimous, in turn reflecting a lack of consensus over school segregation.

This lack of consensus can be seen moreso through an examination of the thirteen vote tallies in the state legislature when deciding whether to pass the Stanley Plan into law. The thirteen laws passed both chambers of the Virginia legislature in September $1956 .{ }^{46}$ Yet in many tallies, the tally was far from unanimous. As Bonastia discusses, the vote for a major bill from this group of thirteen, a law which guaranteed that funds would be cut off for any district that allowed integration, passed sixty-one to thirty-seven in the House of Delegates, and in the Senate, by a slimmer margin of twenty-one to sixteen. ${ }^{47}$ As Bonastia also notes at great length, this lack of consensus in the legislature was in large part a reflection of shifting public opinion. Many districts no longer saw strict segregation as the only answer and were seeing disproportional integration, or token integration, as a more moderate solution. ${ }^{48}$ Despite the split vote, the governor now had the right to create a three-member student placement board responsible for placing every pupil in the state. ${ }^{49}$ Furthermore, he also had the right to close any school that practiced integration, and crucially, could issue tuition vouchers to parents who were

\footnotetext{
${ }^{42}$ Ibid., 70-1.

43 Ibid., 72.

${ }^{44}$ More specifically, one could appeal to the governor. If that did not work, they could then appeal to the state courts. Ibid., 72 .

45 Ibid., 72.

${ }^{46}$ Ibid., 72.

47 Ibid., 73.

48 Ibid., 75.

${ }^{49}$ Ibid., 72.
} 
unhappy with their schools. ${ }^{50}$ At least for the next several months, these laws would continue segregation through the operation of a highly centralized and powerful state government.

Ironically, just as these strict laws were ushered in, massive resistance began to lose its relevance and power in Virginia following the election of the strict segregationist Lindsay Almond in $1957 .{ }^{51}$ Winning in a landslide election with a staggering eighty-three percent of the popular vote, backed by the Byrd machine, and declaring that he would rather cut off his right arm than see integration in his state, Almond would soon astound Virginians by accepting the federal mandates to integrate. ${ }^{52}$ As the federal deadline set by Brown to end segregation by the 1958-59 school year loomed, he and the state began to prepare for the inevitable. At the same time, however, Almond closed down nine mainly white schools in three different counties in September 1958, evicting 12,700 Virginians from schools that federal courts scheduled for integration. He followed this with a speech in November, conceding that Virginia would soon have to integrate. ${ }^{53}$ On January $19^{\text {th }}, 1959$, moreover, the Supreme Court of Appeals of Virginia struck down many of the laws passed to halt integration, among which was the tuition-grant law. $^{54}$

This was quickly followed by a last-ditch effort by conservatives in the state legislature to preserve segregation - even if it meant the governor's incarceration. ${ }^{55}$ Yet, these legislatorsSenator Gray among them-were a minority within a new majority of moderate segregationist legislators who agreed with Almond. Within weeks the group of moderates passed a batch of temporary bills that reformulated tuition grants to a new maximum of $\$ 250$ without any of the

\footnotetext{
${ }^{50}$ Ibid., 72.

51 Ibid., 77.

${ }^{52}$ Ibid., 81.

${ }^{53}$ Ibid., 92.

${ }^{54}$ Harrison v Day, 106 SE 2d 636, 200 Va. 439 - Va: Supreme Court, 1959.

55 Bonastia, 93.
} 
previous reference to race. ${ }^{56}$ Hypothetically, these could allow for integrated schools, but in reality they again were created to circumvent the forced integration required to break the segregated system. Thus, we see a slow movement towards integration, commonly referred to as "token integration," in which a tiny minority of the non-white students were placed within a vast, white majority. As a result, on the second of February 1959, twenty-one African American students began attending integrated schools in two of the infamous counties which had been shut down by Almond the previous fall. Emphasizing how minimal this integration was, these students constituted a body of twenty-one within a population of 6,500 white students. ${ }^{57}$ Significantly, in spite of this token integration, much of the Stanley Plan was continued or resumed the following year under new legislation.

After the legislature's temporary laws expired in April, it implemented a set of new segregation laws under a revised education policy created by a commission headed by the moderate state senator Mosby G. Perrow. ${ }^{58}$ Taking a step away from the strict segregation of the preceding two plans, Perrow's report acknowledged the diminishing "sentiment that it would be better to have no public schools than to have any mixed schools," and urged the legislature to go along with "the majority of people" who were now "unwilling to have the public schools abandoned." 59 The Perrow report then suggested that students in "every locality" be given access to tuition grants, now re-titled "scholarships," for access to nonsectarian private schools. ${ }^{60}$ Significantly, once again they made this suggestion without any mention over whether or not they were for the continuation of segregation. ${ }^{61}$ And in March 1960, the General Assembly

\footnotetext{
56 Ibid., 93.

57 Ibid., 93.

58 Ibid., 95.

${ }^{59}$ Perrow, Mosby G., Report of the Commission on Education to the Virginia, Commonwealth of Virginia Division of Purchase and Printing Richmond, 1955, 6.

${ }^{61}$ Bonastia, Southern Stalemate, 96.
} 
passed a law which guaranteed many of the Perrow Committee's recommendations, allowing "taxpayers to deduct up to 25 percent of real estate and personal property taxes owed for donations to nonsectarian private schools" and increasing the funds for tuition grants or "scholarships." 62 This legislation would guarantee the legality of using vouchers to fund segregated, private education both before and after the public schools had closed in Prince Edward County.

While other counties within Virginia began the process of slow integration, Prince Edward made no provisions. ${ }^{63}$ Similar to many other small counties in the state, within hours of the Brown II decision, citizens of Prince Edward County had gone before its Board of Supervisors and requested that no funds be appropriated for integrated schools. ${ }^{64}$ In June 1955 , in order to support and maintain segregated education in case the public schools were closed, a corporation was founded by school patrons to "provide private education for white children."65 Up until the turnaround by Governor Almond, Prince Edward County and its corporation stood in accordance with the state's every decision.

Yet, white resisters soon found themselves alone in the belief that resistance could prevail at all costs. As Bonastia points out, their perseverance was in large part a result of the efforts of another strong-willed legal figure backed by the Byrd machine, Judge Sterling Hutcheson. Overseeing the Prince Edward Case beginning in mid-1956, within a year the judge flatly refused to "set a deadline for the county to begin desegregation" on behalf of the county, an order which was not vacated until April $1960 .{ }^{66}$ By this point the county public schools had

\footnotetext{
${ }^{62}$ Ibid., 97.

${ }^{63}$ Ibid., 99.

${ }^{64}$ Ibid., 63.

${ }^{65}$ Ibid., 63.

${ }^{66}$ Ibid., 98.
} 
already closed and Hutchenson had retired from the bench. ${ }^{67}$ Prince Edward, therefore, had a legal order forbidding the end of segregation within its own jurisdiction, even if it meant the elimination of public schools. As a result, the county decided to close its schools on June $2^{\text {nd }}$, $1959 .{ }^{68}$ Less than a month later, it decided against the allocation of any funds for the coming school year, including any for the currently illegal practice of vouchers. This in turn reduced property taxes by 53 percent. Much of these funds would be used by county residents to fund a newly created private academy. ${ }^{69}$

The 1959-60 school year fell between the discontinuation of the temporary legislative package, which guaranteed tuition grants, and the official law passed by the General Assembly in March 1960. In spite of the closure, though, and in spite of the lack of available funds, the county decided to provide segregated education through a privately funded academy. Using the Farmville High School campus as its facility, officials assisted Prince Edward Academy to serve the white residents of the county. ${ }^{70}$ Then, after the March 1960 decision by the General Assembly to grant $\$ 125$ to $\$ 150$ in tuition grants, the Prince Edward Board of Supervisors passed its own ordinance guaranteeing tuition grants of $\$ 100$. This ordinance, combined with a County Board of Supervisors measure "allowing tax credits up to $25 \%$ for contributions to any 'nonprofit, nonsectarian private school' in the county," provided for a well-funded, segregated academy where the average parent could receive up to $\$ 250$ annually for tuition. ${ }^{71}$ This arrangement would remain unchallenged until the following school year, when a local reverend from the African American community, L. Francis Griffin, filed a petition questioning the

\footnotetext{
${ }^{67}$ Ibid., 98.

${ }^{68}$ Ibid., 99.

${ }^{69}$ Ibid., 100.

${ }^{70}$ Ibid., 107.

${ }^{71}$ Griffin v Board, section 224.
} 
legality of such segregation and the exclusion of African American children from any educational services whatsoever.

As a result of Griffin's action the Virginia Supreme Court of Appeals denied the county the right to "assess taxes and allocate funds to operate public schools" in March 1962. ${ }^{72}$ This soon convinced people that the schools would reopen in the fall, but these hopes proved unrealistic. Without the availability of tax funds for tuition vouchers, the county did not return to private donations, and instead lowered the property tax rates, allowing parents to pay their tuition "out of pocket." ${ }^{, 73}$ This system would sustain itself for another two school years.

By the end of 1963, it had been a dozen years since the African American community in Prince Edward County had begun its active struggle to end inequality in the public school system. Throughout the public school closure, black leaders had been offered funds to create the equivalent of a black Prince Edward County Academy, offers which they quickly dismissed. ${ }^{74}$ Using vouchers to fund a separate academy would simply return to a segregated status quo. African American leaders sought federal intervention once they realized the county and state were unwilling to budge. It would be another half decade before this perseverance paid off. In the meantime, an emerging set of voucher proposals would attract the attention of the Johnson and Nixon administrations.

\footnotetext{
${ }^{72}$ Bonastia, Southern Stalemate, 136.

${ }_{74}^{73}$ Bonastia, Southern Stalemate, 137.

${ }^{74}$ Ibid.
} 


\section{Chapter III: National Attention - The Emerging Voucher Ideologies of Blum and Friedman}

Contrary to the facts of history, contrary to the continuing mind of the American people, contrary to the general burden of Supreme Court decisions, it is still vehemently asserted in certain quarters that due recognition of the independent school as a public educational institution performing a public educational function would be a violation of the establishment-of-religion clause in the First Amendment to the Federal Constitution. Any plan for encouraging pluralism and freedom of choice in education can hardly afford to ignore this side of the problem

—Will Herberg, social philosopher and Jewish theologian ${ }^{75}$

In June 1959, the same month the schools closed in Prince Edward County, the Virginia journalist Leon Dure wrote to Virgil C. Blum, a Jesuit Priest and professor of political science at Marquette University in Milwaukee, Wisconsin in order to seek advice on how to handle the situation currently unfolding in his county. ${ }^{76}$ Dure was fascinated by the similarities between Blum's recent work on the potential of a similar form of tuition voucher to those being issued by the Virginia General Assembly. Blum had written extensively on the potential for "school vouchers" to create an open, competitive "market" between public schools and private schools, regardless of whether they were sectarian or not. Dure had received Blum's seminal work Freedom of Choice in Education (1958) as a gift from a Virginian Catholic priest, and "was startled to find" arguments similar to the ones he had "been waging in Virginia for a long time." However, it would take a year and a half for Blum to respond to his letter. ${ }^{77}$

Blum was unique in many ways. Freedom of Choice in Education was the first coherent monograph on the perceived benefits of vouchers in education, apart from an article by free-

\footnotetext{
${ }^{75}$ Blum, Virgil C., Freedom of Choice in Education. (New York: Macmillan, xii-xiii, 1958).

${ }^{76}$ Carl, Jim. 2011. Freedom of Choice: Vouchers in American Education. Santa Barbara (Calif: Praeger, 2011), pp. 92.

${ }^{77}$ Ibid., 92.
} 
market economist Milton Friedman published in 1955. In fact, Blum was the first to speak of this concept since Adam Smith and John Stuart Mill had briefly alluded to similar, albeit different, concepts in the late-eighteenth and mid-nineteenth centuries respectively. ${ }^{78}$ Drawing on the imagery of a totalitarian state like the contemporary Soviet Union, Blum sought to argue that vouchers were the way to avoid "the complete loss of individuality and identity"79

The individual person, once free and self-determining, is in danger of being progressively more and more caught up into the orbit of government control and regulation through the imposition of restrictive controls as the condition for sharing in the benefits of welfare legislation. ${ }^{80}$

More pointedly, he insisted that "if forced to choose between two so great evils as government control, on the one hand, of the kind and quality of food one must eat, and, on the other hand, of the kind and quality of thoughts one must think, surely no American with a sense of the importance of freedom of thought would hesitate in making his choice." ${ }^{\prime 1}$

Blum was also the first to rationalize the feasibility of vouchers by comparing them to the G.I. Bill, which granted federally funded tuition scholarships to returning veterans after the Second World War. ${ }^{82}$ In 1961, Blum would found Citizens for Educational Freedom (CEF), a powerful voucher lobby, in order to continue his advocacy for vouchers throughout the nation. ${ }^{83}$ Thus, as can be seen in the exchange between the priest and Dure, the similarity of concerns over

\footnotetext{
${ }^{78}$ Policy advocates from this era were almost unanimous in their belief that the voucher dated back 150 years to Smith and Mills and the dawn of democratic liberalism. While this may be true-they did in fact discuss the idea of having rational individuals select their own form of education through the power of their money and intuition - they did not, however, advocate these ideas at a time comparable to the late 1960s. "In this portion of his classic work On Liberty (1859), John Stuart Mill strives to prove that, contrary to sentiment in mid-Victorian England, education is a societal responsibility. His desire to reconcile that premise with his generally libertarian attitude against government intervention led him to suggest an educational voucher system. He believed this arrangement could assist poor families without creating the justification for state control of the curriculum." LaNoue, George R. 1972. Educational Vouchers: Concepts and Controversies. New York: Teachers College Press, 2.

${ }^{79}$ Carl, Freedom of Choice, 2.

${ }^{80}$ Blum, Freedom of Choice in Education, 3.

${ }^{81}$ Ibid., 36.

${ }^{82}$ Ibid., 136.

${ }^{83}$ La Noue, Educational Vouchers, 20.
} 
an increasing government takeover and Southern hostility to federal intervention with concepts of "freedom of choice" were convenient for both political agendas. Blum wanted federal funding for parochial private schools, while the South sought to preserve its "way of life."

Three years prior to Blum's publication, Milton Friedman had published an article titled "The Role of Government in Education" in the edited volume, Economics and the Public Interest. His article would adopt the first widespread use of the word "voucher" beyond the realm of segregation. A lifelong advocate of neo-liberal policies, especially in relation to economic deregulation, Friedman would come to dominate the cause for vouchers and in turn raise public awareness about the concept over subsequent decades. ${ }^{84}$ Under the voucher system, he wrote,

The role of the government would be limited to assuring that the schools met certain minimum standards such as the inclusion of a minimum common content in their programs, much as it now inspects restaurants to assure that they maintain minimum sanitary standards. An example of a program of this sort is the United States educational program for veterans after World War II, provided they meet minimum standards. ${ }^{85}$

As historian Jim Carl has noticed, however, a discrepancy exists between Friedman's original article and the second, more widely read version from his widely disseminated work Capitalism and Freedom (1962). ${ }^{86}$ In 1955 Friedman was careful to include a footnote about use by several southern states of vouchers "as a means of evading the Supreme Court ruling against segregation. ${ }^{87} \mathrm{He}$ does not see this, however, as a reason to disregard the concept of vouchers. Instead, he argues that "principles can be tested most clearly by extreme cases" and that individuals could be left to their rational faculties in order to determine that forced segregation is

\footnotetext{
${ }^{84}$ Carl, Freedom of Choice, 17.

${ }^{85}$ Friedman, Milton, "Economic Policy \& Social Control: Role of Government in Education" in Solo, Robert A., Economics and the Public Interest. [Essays written in honor of Eugene Ewald Agger]. (New Brunswick, N.J.: Rutgers University Press, 1955), pp. 128.

${ }^{86}$ Carl, Jim, "Free Marketeers, Policy Wonks, and Yankee Democracy: School Vouchers in New Hampshire, $1973-$ 1976" (Harvard Educational Review. 78 [4], 2009), pp/ 595

${ }^{87}$ Friedman, Milton, "Economic Policy \& Social Control: Role of Government in Education," pp. 128.
} 
unjust. ${ }^{88}$ Friedman feels that any form of forced schooling is unjust, even forced integration.

Instead, he suggests,

Privately conducted schools can resolve the dilemma. They make unnecessary either choice [between a forced segregation system and a forced integration system]. Under such a system, there can develop exclusively white schools, exclusively colored schools, and mixed schools. Parents can choose which to send their children to. The appropriate activity for those who oppose segregation and racial prejudice is to try to persuade others of their views; if and as they succeed, the mixed schools will grow at the expense of the nonmixed, and a gradual transition will take place. So long as the school system is publicly operated, only drastic change is possible; one must go from one extreme to the other; it is a great virtue of the private arrangement that it permits a gradual transition. ${ }^{89}$

Significantly, in the revised version of the article included in Capitalism and Freedom seven years later, the footnote was completely omitted.

Crucially, Blum, like Friedman, was reluctant to take a stance on segregation. Carl puts it even more bluntly. "In the end," he states, "Blum took the same tack that Milton Friedman adopted after 1955 regarding southern tuition grants—in his published writings, they did not exist." ${ }^{90}$ Fundamentally, segregationists conflicted with both Blum and Friedman's ideology for unregulated "freedom" when they did not offer tuition vouchers towards parochial schools.

Similar to modern voucher advocates, they felt any school, private or public, should be able to compete with one another, although using the idea as a means for government to control a segregated system did not bode well for their ideologies or public image.

Contrary to the desires of Blum and Friedman, though, over the next decade the federal government would increase its involvement in primary and secondary education in unprecedented ways. Both the funding and curricular control over education would increase as a result of the passage of the Elementary and Secondary Education Act (ESEA). Ironically, as a

\footnotetext{
${ }^{88}$ Ibid., 128.

${ }^{89}$ Ibid., 128.

${ }^{90}$ Carl, Freedom of Choice, 92.
} 
result of this increased support, the government would soon look towards funding primary and secondary education in a more efficient and less costly manner. One of the alternative models would once again be vouchers. Yet, the vouchers initially advocated by Northeastern Democratic liberals were highly different from those advocated by laissez-faire economists, religious figures, and segregationists. Instead, they were tightly regulated in order to prevent another situation like the shutdown in Prince Edward County from happening again. 


\section{Chapter IV: Intervention and the Emergence of the Voucher Concept at the Federal Level}

The schools in Prince Edward County eventually reopened as a result of executive action by President John F. Kennedy. Unlike President Dwight D. Eisenhower, who failed to explicitly respond or take any executive action in reaction to the closure of the schools, Kennedy was outraged to discover schools had been closed for over eighteen months when he took office in January $1961 .^{91}$ The following year, the president called on his brother, Attorney General Robert Kennedy, to respond to the situation. While Title IV of the Civil Rights Act of 1957 did allow the Attorney General the authority to intervene in specific voting right cases, it did not grant the same authority regarding desegregation. ${ }^{92}$ As a result, the Justice Department spent months waiting for an invitation from the courts to intervene as a "friend of the court" in Prince Edward

County. ${ }^{93}$ In the last week of April, Robert Kennedy grew tired of waiting, and on the recommendation of Assistant Attorney General Burke Marshall he decided to intervene as a party plaintiff. Further, he requested that the federal court "order the state of Virginia to withhold state money from all public schools until Prince Edward County's public schools re-opened."94 Again, this request was not granted, and the schools remained closed.

In response to being denied the right to take legal action to reopen the schools, the Kennedy administration decided it would attempt to open and run private schools within the county. After soliciting advice from the Justice Department, President Kennedy decided that he would coordinate the creation of a free private school system for the 1963-64 school year, aptly

\footnotetext{
${ }^{91}$ Hicks, Terence, and Abul Pitre, The Educational Lockout of African Americans in Prince Edward County, Virginia (1959-1964): Personal Accounts and Reflections (Lanham, Md: University Press of America, 92 Ibid., 20. 2010), pp. 20.

93 Ibid., 21.

${ }^{94}$ Ibid., 22.
} 
named the "Free Schools." ${ }^{.95}$ Operated on behalf of a bi-racial board and funded through private donations-including the largest ones by the Ford Foundation and Field Foundation, as well as the president himself—-to reach the projected budget of $\$ 1$ million, the Free School Association opened four renovated buildings for roughly 1,500 students on September 16, $1963 .{ }^{96}$

Meanwhile, the legal decision over whether or not to enforce the reopening of the public schools remained in Court. After the U.S. Fourth Circuit Court of Appeals ruled two-to-one in favor of the county, the NAACP made an appeal to the U.S. Supreme Court. ${ }^{97}$ This appeal would result in Griffin v County School Board, and would finally lead to the reopening of the schools on May $26^{\text {th }}, 1964 .^{98}$ Yet, the Supreme Court did not decide whether or not the tuition vouchers were legal. As a result, when the public schools reopened, the public schools were almost entirely African American in enrollment, while white students remained at Prince Edward Academy and other private schools through the support of the vouchers and tax deductions. ${ }^{99}$ In the end, an estimate by Edward Peeples, a local academic from Virginia Commonwealth University and active civil rights leader, suggested "that 2,694 black students were locked out of public schools from 1959 to 1965, with 492 receiving some years of education elsewhere," as opposed to the 258 out of 2,118 white students who received insubstantial education as a result of the closings. ${ }^{100}$ Many of these African American students would be subsequently seen as a lost generation, for many did not return to school or suffered the pains of being several years behind in basic subjects.

\footnotetext{
95 Bonastia, Southern Stalemate, 140.

${ }^{96}$ Hicks, Terence, Educational Lockout, 26.

97 Ibid. 27.

${ }^{98}$ Griffin Et Al. v. County School Board of Prince Edward County, 377 U.S. 218 (1964).

${ }^{99}$ Boanstia, Southern Stalemate, 152. As he states, "the Free Schools were open to both races, eventually enrolling eight whites among the 1,578 students."

${ }^{100}$ Boanstia, Southern Stalemate, 160.
} 
As can be seen, the federal involvement far surpassed the county or the state in reinstating public, unsegregated education in Prince Edward County. Yet, even after the schools had reopened, the system of tuition vouchers, and therefore segregation, would not officially end until the U.S. District Court of Virginia ruled in a second Griffin v State Board of Education case that the county school board was indeed upholding an unconstitutional, segregated system. The Court declared that by the end of the 1968-69 school year vouchers must be discontinued. ${ }^{101}$

While this court case was winding down in 1968, the administration of Lyndon B. Johnson began to investigate the benefits of tuition vouchers within the context of the Great Society. Relying on a new generation of young social scientists at the Harvard School of Public Policy who were advocating for a new, regulated form of vouchers, both Johnson and his successor, Richard Nixon, would consider vouchers as a potential form of primary and secondary education funding. Through an analysis of the contested segments of the ESEA, the political context from which the discussion of vouchers reemerged, and the ensuing voucher experiment, one can chart the emergence of a conservative approach to elementary and secondary education funding often neglected by scholars. ${ }^{102}$

A decade earlier, it would have been unimaginable for a president to authorize, or even look into, federal policy on education. Prior to the 1960 election, when Richard Nixon ran against John Kennedy, debate over teachers' salaries or a child's right to read was wholly neglected during presidential campaigns. This can also be said of White House administrations. In 1949, future president Dwight Eisenhower warned in a letter to Congressman Ralph Gwinn that "unless we are careful, even the great and necessary educational processes in our country

\footnotetext{
${ }^{101}$ Griffin v. State Board of Education, 296 F. Supp. 1178-Dist.

${ }^{102}$ Few historical accounts exist. For a brief account on the origins of vouchers see Jeffrey, Julie Roy, Education for Children of the Poor: A Study of the Origins and Implementation of the Elementary and Secondary Education Act of 1965 (Columbus: Ohio State University Press, 1977).
} 
will become yet another vehicle by which the believers in paternalism, if not outright Socialism, will gain still additional power for the central government." ${ }^{103}$ Yet the assassination of John Kennedy produced a momentum in favor of liberal policy in both chambers of Congress, augmented by Democratic gains in the election of 1964. More importantly, when Lyndon Johnson, a former public school teacher himself, saw the chance to fulfill a lifelong ambition to succeed in a way that no liberal had done before in the realm of education, he signed the ESEA in 1965, creating the single largest overhaul and increase in federal involvement in U.S. history. $^{104}$

The final vote on ESEA was largely reflective of the liberal Democratic majority in the House of Representatives following President Johnson's landslide victory in 1964. Crucially, only thirty-five of 131 House Republicans and forty-one of ninety-five Southern Democrats originally voted for the bill. In the Senate, however, the vote was largely bi-partisan. Of twentytwo Senate Republicans, only four opposed the measure while only four out of nineteen Southern Democrats voted no. Over the following decade these majorities would steadily increase until in 1978 the vote to renew ESEA was 350 to twenty in the House and eighty-six to seven in the Senate. ${ }^{105}$

The 1965 bill was divided into five initial titles. Title I accounted for five-sixths of the total funds available (about $\$ 1$ billion for the first year alone), and was in large part aimed

\footnotetext{
${ }^{103}$ Davies, Gareth 2008, "Towards Big-Government Conservatism: Conservatives and Federal Aid to Education in the 1970s". Journal of Contemporary History. 43 (4), 625. The original source: Letter, Eisenhower to Cong. Ralph Gwinn (Republican-New York), 7 June 1949, in Public School Assistance Act of 1949, Hearings before a Special Subcommittee of the Committee on Education and Labor, House of Representatives, $81^{\text {st }}$ Congress, $1^{\text {st }}$ Session (Washington, D.C., 1949), 888.

${ }^{104}$ For an in depth discussion on this topic see Graham, Hugh Davis. 1984. The uncertain triumph: federal education policy in the Kennedy and Johnson years. Chapel Hill: University of North Carolina Press. For a view which suggests that Kennedy was more successful as a legislator than historians have previously suggested, see Bernstein, Irving. 1991. Promises kept: John F. Kennedy's new frontier. New York: Oxford University Press.

105 Statistics taken from Congressional Record Almanac, found in Davies, Gareth 2008, "Towards Big-Government Conservatism: Conservatives and Federal Aid to Education in the 1970s". Journal of Contemporary History. 43 (4), 626.
} 
towards funding programs for children from low income families earning less than an annual $\$ 2,000$ who attended both public and private schools. Title II guaranteed $\$ 100$ million in order to fund library resources and textbooks for the same student body over the first five years of the program. Title III was mainly created to provide funding for physical education and recreational facilities, adult education, and educational counseling; while Title IV funded research by universities and other agencies on non-sectarian educational issues. Title $\mathrm{V}$ provided funding for basic upgrades to school facilities and state departments of education. In 1966 and 1967, an additional two titles would be passed by Congress: Title VI providing aid to handicapped children, and Title VII providing aid to bilingual education programs. ${ }^{106}$

Significantly, the ESEA did not allow for any national curriculum, and relative to local funding, it was still small in its contributions. Rather, its main objective was to improve the quality of education for those who needed it, namely the impoverished. Significantly, early assessments of the efficacy of these initial five titles were nearly unanimous in their opinion that the ESEA was proving far less effective than legislators had supposed.

Despite the initial overriding congressional support for the ESEA, the first three years of its existence would indeed provide a number of headaches for policymakers. Historians have pointed out that the Johnson administration's careful and methodical approach to the bill's passage contrasted with a lack of planning in regards to its implementation. ${ }^{107}$ Over the course of the ensuing years, renewed opposition, especially on behalf of the growing conservative movement, would intensify because of the faulty implementation of the bill. Yet the criticism

\footnotetext{
${ }^{106}$ Patrick McGuinn and Frederick Hess, The Great Society and the High Tide of Liberalism, ed. Milkis, Sidney M., and Jerome M. Mileur (Amherst: University of Massachusetts Press, 2005), 295.

${ }^{107}$ Numerous studies have been published in regards to the lack of preparation for the bill's operation. Apart from Hugh Davis Graham's work, see Jeffrey, Julie Roy, Education for Children of the Poor: A Study of the Origins and Implementation of the Elementary and Secondary Education Act of 1965 (Columbus: Ohio State University Press, 1977) and Milkis, Sidney M., or Jerome M. Mileur, The Great Society and the High Tide of Liberalism (Amherst: University of Massachusetts Press, 2005).
} 
would come not in response to questions of whether or not the federal government should have an active role in education, but rather in response to how it should involve itself. Deciding to use vouchers as a major component of this fight against "big government" stands as an unusual choice, especially since recent examples like Prince Edward County and the state of Virginia showed how controversial vouchers could be depending on their use.

From the beginning of its operation, many opponents of the ESEA had criticized how funds were distributed, as well as the amount of money being distributed. Significantly, the bill was categorical, meaning that funding was aimed at specific programs or recipients. In spite of a few local school administrations circumventing the measure's legal specificities, therefore, little of the money was given to local officials to use at their own discretion. ${ }^{108}$ To complicate matters, many Title I programs did not fulfill the aim of raising achievement levels or student retention. ${ }^{109}$ This assessment in large part derives from the evidence found in the evaluation clauses that the Johnson administration created to ensure that an initial biennial evaluation report on the progress of Title I programs be produced by 1967. These mandatory evaluations became especially noteworthy for conservatives, for they were often negative in their findings, and provided the opportunity for alternative ideas. ${ }^{110}$

Even before the first biennial report, sociologist James Samuel Coleman had produced a regression analysis, Equality of Educational Opportunity (1966), which emphasized that in the case of minority students, schooling had little impact on future success in comparison to socioeconomic background. ${ }^{111}$ This would begin to affect executive policy decisions during the

\footnotetext{
${ }^{108}$ Unger, Irwin, The Best of Intentions: the Triumphs and Failures of the Great Society Under Kennedy, Johnson, and Nixon (New York: Doubleday, 1996), 126.

${ }^{109}$ Ibid., 353.

${ }^{110}$ Divine, Robert A. 1981. Exploring the Johnson years. Austin, Tex: University of Texas Press, 171.

${ }^{111}$ As later historians would note-namely Julie Roy Jeffries and Hugh Davis Graham-this evaluation clause would also provide concern, for the results were more often than not were unsatisfactory.
} 
final year of the Johnson administration. In the case of vouchers, an effort was led by the Office of Economic Opportunity (OEO), which, as historian Jim Carl has noted, was an unusual choice considering its track record with large-scale welfare programs like Head Start, Model Cities, and Community Action over the previous five years. ${ }^{112}$ Yet, towards the end of the president's terms, Johnson's appointees were desperate for alternatives to the large-scale funding projects which were now being criticized. Additionally, the head of OEO at the time, Sargent Shriver, was a supporter of tax credits for families attending private schools. Accordingly, the Johnson administration offered federal funding to school districts "willing to experiment with compensatory vouchers," although no districts participated. ${ }^{113}$

President Nixon made more of an effort to plan and conduct studies around the feasibility of vouchers. As a result, it would be nearly three years, before the Nixon Administration would make a similar offer. First, the new administration backed increased funds for ESEA, even though it eventually abandoned this in favor of more conservative plans. As historian Gareth Davies has argued, the desire to increase federal involvement in education was rather strong during the first couple of months of Nixon's tenure. ${ }^{114}$ Yet, by the end of the year, the administration decided to place emphasis on researching alternative, less costly methods to fund elementary and secondary education and propose drastic reductions and revisions on how funding should be re-designated to produce more efficiency.

Often citing the Coleman Report, Nixon would urge listeners, as he did in March 1970, to "recognize that our present knowledge about how to overcome poor background, is so limited

${ }_{112}^{112}$ Blum, Freedom of Choice in Education, 63.

${ }^{113}$ Ibid., 64

${ }^{114}$ Davies includes a similar discussion of the reform impulse of the Nixon administration and the unlikely decision by the administration to push for a seventh title for the original ESEA in a call for bilingual education. He reasons this effort was a result of the administration's desire to win over the latino demographic. See, Davies, Gareth. 2002. "The Great Society after Johnson: The Case of Bilingual Education". The Journal of American History. 88 (4): 1405-1429. 
that major expansion of such programs [as the ESEA] could not be confidently based on [previous researchers'] results." ${ }^{\text {115 }}$ Nevertheless, Congress featured a Democratic majority in both chambers, as it had since $1955 .{ }^{116}$ Consequently, when Nixon delivered a speech to Congress in September 1970, arguing that ESEA programs were "based on faulty assumptions and inadequate knowledge," he was largely ignored. ${ }^{117}$ During the rest of his administration, legislation on the matter often failed to reach the floor for a vote. Consequently, the White House was slow to abandon funding of the program or seek to restructure it.

Despite or because of Nixon's inability to restructure federal aid to public education through legislation, he proposed that a Commission on School Finance be enacted and a National Institute of Education (NIE) be created in 1971 to research alternative ways to educate the nation's youth in a more effective and less costly manner. With money no longer seen as the answer, the NIE sought to effectively undermine the large sums of Title I funds issued to school districts. Beginning in 1972, with a modest budget of $\$ 90$ million, the agency began doing research on compensatory funding ${ }^{118}$ for education and more reliable evaluation techniques for assessing education programs. ${ }^{119}$

The administration's search for alternatives collided with the goals of James Allen, Jr., Nixon's Commissioner of Education, a position within the Office of Education, which in 1972 became re-titled the Assistant Secretary of Education. The former head of the New York State Board of Education had a particularly liberal bent. Among his top priorities was a federally funded initiative to improve literacy rates among the nation's children. Allen shared Johnson's

\footnotetext{
${ }^{115}$ Congressional Quarterly Weekly Report 28 (1970): 715.

116 Not until 1981 do we see a Republican majority in either chamber of Congress.

${ }^{117}$ Milkis, Sidney M., and Jerome M. Mileur, The Great Society and the High Tide of Liberalism (Amherst: University of Massachusetts Press, 2005), 307.

${ }_{118}$ Compensatory funding simply means that the effort is to compensate for the child's lack of opportunity in life.

${ }^{119}$ Hearings before the Select Committee on Equal Educational Opportunity of the U.S. Senate, 92d Cong., $1^{\text {st }}$ Sess., 1971, Senate, p. 5818.
} 
belief that increased funding was paramount. Unlike Johnson, however, he also felt that the time was ripe for reform. Nevertheless, by late 1969, Allen found himself at odds with Daniel Patrick Moynihan, Nixon's chief domestic advisor, and Robert Finch, the Director of the Department of Health, Education, and Welfare (HEW), over funding levels. ${ }^{120}$

Allen's dissatisfaction with administration policy surfaced in a letter to Nixon in May 1970 pleading for "a higher priority" for education and an allocation of one billion dollars above the present ceiling for HEW for the coming fiscal year. Allen cited several critical areas, including "early childhood education, the Right to Read, education for the handicapped, vocational education, institutional aid for higher education, and environmental-ecological education." 121 The assistant secretary begged that the needs of children could not be put in "deep freeze" in spite of fiscal concerns. When the administration did not respond, Allen resigned the following month. ${ }^{122}$

In an interview in November 1970, Allen spoke critically of his time as Commissioner of Education. Specifically, he referred to his intention while in office to make a lasting impact on education and avoid being "the chief administrator of a collection of check writing units." ${ }^{, 23}$ At the same time, Allen addressed the challenges he faced from the bureaucratic structure, as well as an inflation-wary Nixon administratio that undercut any idea of "a vigorous program in urban education" that would require "large sums allocated for a more concerted and systematic attack

\footnotetext{
${ }^{120}$ Davies, Gareth. 2002. "The Great Society after Johnson: The Case of Bilingual Education". The Journal of American History. 88 (4): 1409.

${ }^{121}$ Ibid., 537.

122 Disagreements with the President's decision to invade Cambodia also factored into Allen's decision.

${ }^{123}$ James Allen Jr. “An Interview with James Allen,” Harvard educational review. Cambridge, Mass: Harvard University, Winter 1970, 534.
} 
on the problems of the inner-city schools." ${ }^{124}$ Nixon's efforts for well-funded federal education policy had ended.

${ }^{124}$ Ibid., 535. 


\section{Chapter V: Low Scores at Alum Rock}

By the time Allen resigned, the Nixon administration no longer saw large-scale funding as the solution. Instead, it decided to turn towards new research and alternative forms of educational support. This came from a group of neo-conservatives working in the Office of Economic Opportunity (OEO) under Donald Rumsfeld. The OEO, the central office created to administer Johnson's Great Society, and Rumsfeld, a conservative congressman from Chicago who deplored welfare programs, were an odd fit. Nevertheless, Nixon asked Rumsfeld to head OEO in early $1969 .{ }^{125}$ Contrary to the belief of pundits at the time, after diminishing the power of the Civil Rights Division and Legal Services with his assistant Richard Cheney, Rumsfeld refrained from dismantling the OEO during his year as director. ${ }^{126}$ Rather, he placed an emphasis on welfare programs which coincided with the emerging free-market ideology. Vouchers were one of these alternative programs. ${ }^{127}$

While a Democratic Congress and a conservative White House battled over the appropriation of HEW funds and increases to Title I, the OEO began investigating vouchers. ${ }^{128}$ The ideology for vouchers Rumsfeld and his team advocated stemmed from the work of a Harvard professor of Education, Christopher Jencks. Jencks began pressing for vouchers in 1966 in articles in Public Interest and Dissent that expressed his growing conviction that vouchers were a good solution as much of the nation descended into race-riots and political violence. ${ }^{129}$

\footnotetext{
${ }^{125}$ Carl, Free Marketeers, Policy Wonks, 591).

${ }^{126}$ Carl, Freedom of Choice, 64.

127 Ibid., 64.

${ }^{128}$ Historian Julie Roy Jeffreys notes that between 1969 and 1973 an estimated \$1 billion of education funds were blocked from reaching their congressionally approved destinations as a result of Nixon's executive veto power. Jeffrey, Julie Roy, Education for Children of the Poor: A Study of the Origins and Implementation of the Elementary and Secondary Education Act of 1965 (Columbus: Ohio State University Press, 1977), 206

${ }^{129}$ Carl, Freedom of Choice, 65.
} 
Notably, he was quoted in a 1968 edition of the New York Times Sunday Magazine. "The best alternative I can see," stated Jencks, "is to follow the Catholic precedent and allow [black] nationalists to create their own private schools, outside the regular public system, and to encourage this by making such schools eligible for substantial tax support.." ${ }^{130}$ Working under a grant provided by the Office of Economic Opportunity, Jencks was among a batch of liberal scholars who sought to create a more effective public school system that would place the power back in the hands of the parents. ${ }^{131}$ In December 1969, they began their OEO-commissioned feasibility study on vouchers at the Center for the Study of Public Policy in Cambridge, Massachusetts.

Crucially, Jencks was an advocate for regulated vouchers, also known under the label of the "compensatory voucher model." In his 220-page report Education Vouchers: A Report on Financing Elementary Education by Grants to Parents, Jencks and his assistant Stephen Arons, a Harvard attorney, assertively opposed the unregulated voucher model. ${ }^{132}$ In line with the Office of Economic Opportunity's central ideal, Jencks was hoping to benefit the poor and minority groups. For this reason, he advised that extra funding be granted to these groups, and that no schools be allowed to discriminate or deny admission based on race. ${ }^{133}$ Noting that by "creating a completely free market for schooling," increased segregation characterized matters of "race, income, and ability,"134 he argued that "an unregulated voucher system could be the most serious setback for the education of disadvantaged children in the history of the United States." ${ }^{135}$ At the

\footnotetext{
${ }^{130}$ Ray Rist, Restructuring American Education 1972, 181.

${ }^{131}$ Jeffrey, Julie Roy, Education for Children of the Poor: A Study of the Origins and Implementation of the Elementary and Secondary Education Act of 1965 (Columbus: Ohio State University Press, 1977), 184.

132 Jencks, Christopher, Giving Parents Money to Pay for Schooling: Education Vouchers (Cambridge, Mass: The Center for Educational policy Research, Harvard Graduate School of Education, 1970), pp. vii.

${ }^{133}$ LaNoue, George R. Educational Vouchers; Concepts and Controversies. New York: Teachers College Press, 1972), pp. 156-157.

${ }^{134}$ Ibid., 6.

${ }^{135}$ Ibid., 17.
} 
same time, the report also pointed to the paradox, that if a voucher system was too rigid in its regulations, it might "be indistinguishable from the present public school system."136 Alum Rock would prove this estimation to be true.

Since the proposed demonstration at Alum Rock was experimental research it did not require legislative approval. Yet opinions for and against voucher philosophies would emerge in a series of hearings in Congress. Between 1970 and 1971, officials and educators from the National Education Association (NEA) - the largest education lobby in the country, made up of both teachers and administrators-descended upon Capitol Hill to oppose vouchers. Their position was later mirrored in a study from the Rand Corporation think tank in California for the National Institute of Education, A Public School Voucher Demonstration: The First Year at Alum Rock, which argued the following:

A second important objection is that the new system, bent on attacking the perceived sameness of our public schools, will destroy the democratic values that public schools share and instill. Almost all Americans who have gone to school in the past century have attended public schools. The schools have been the greatest single institutional force for transmitting American values and socializing children from variegated backgrounds. A voucher system, by prizing diversity and encouraging the breakup of uniformity, could undermine that vital role of American public education ${ }^{137}$

Additional testimony suggested that vouchers would leave only the impoverished and unintelligent students in public schools, while the affluent and gifted would go to private institutions. In support of such objections, public school establishments flocked to Capitol Hill in 1971 to oppose the proposed demonstrations. ${ }^{138}$ Frank Carlucci and John Wilson, the director

\footnotetext{
${ }^{136}$ Jencks, Christopher. 1970. Giving Parents Money to Pay for Schooling: Education Vouchers. Cambridge, Mass: The Center for Educational policy Research, Harvard Graduate School of Education.,ix.

${ }^{137}$ Weiler, Daniel, and Pierce Barker, A Public School Voucher Demonstration, the First Year at Alum Rock: Prepared for the National Institute of Education (Santa Monica, Ca: Rand, 1974), pp. 5

${ }^{138}$ Among the groups who went was the National Education Association, the American Federation of Teachers, the American Association of School Administrators, the National School Boards Association, and the National Congress of Parents and Teachers; and religious, the Baptist Joint Committee and the American Jewish
} 
and assistant director of the Office if Economic Opportunity (OEO), respectively, were called to a special hearing by the Senate subcommittee on Employment, Manpower and Poverty of the Committee on Labor and Public Welfare on April $27^{\text {th }}$. In a rather intense exchange between the two directors and Democratic Senator Gaylord Nelson of Wisconsin, Carlucci defined vouchers as a test "which places a premium on the admission of poor students and which promotes diversity in educational options for the children of the poor." ${ }^{, 139}$ Under the admission that Title I was not effectively addressing the needs of poor children, it became hard for Senators to disagree with an alternative experiment. Nevertheless, Nelson failed to see why additional money should be spent on a new, untested experiment when funds were being stripped from effective programs such as the Teacher Corps-another Great Society program aimed at providing low income areas with high quality teachers.

In a similar fashion, Representative Peter A. Peyser, Democrat of New York showed little enthusiasm for vouchers. Vouchers, he declared in October 1971, would lead to the closing of urban schools and "the emergence of a few exclusive private schools to replace them, leaving the inferior public school as a dumping ground for some children who did not move, or who were expelled from the private schools." ${ }^{140}$ Peyser cited a letter he had recently received from Assistant OEO Director John Wilson in regards to his critiques. Wilson assured Peyser that the planned demonstrations were "limited and experimental" and that they would not "undertake any full-scale experiment unless there are indications of wide support for it within the community to be served." ${ }^{141}$ On the other side of the argument, Republican Senator Strom Thurmond of South 
Carolina claimed that education vouchers could effectively break "the interest of government to impose a monopoly on its people."142 143

Despite these discussions and criticism, the OEO authorized funds to produce voucher feasibility studies for four school districts in 1971, based on the report produced by the Center for the Study of Public Policy under Jencks and Arons. As a result of this authorization, the Alum Rock district in San José agreed to participate in the program for five to seven years. The other three school districts-Gary, Indiana; San Francisco, California; and Seattle, Washington—opted out over doubts about vouchers and opposition from local public school teacher organizations. ${ }^{144}$ In the end, Alum Rock was the only school district in the nation to participate.

Creating a compromise between OEO and the school district about what sort of feasibility study the district wanted to implement would prove to be the biggest obstacle to obtaining state board approval. ${ }^{145}$ Early in 1971, a vote on whether or not to approve a feasibility study which closely resembled the compensatory voucher outline by Jencks was purposefully postponed by superintendent Jefferds because he knew that teachers and local residents would halt the proposed experiment if it were to reach the board. ${ }^{146}$ The postponement, Jefferds felt, would give him and his school district the necessary time to convince OEO to alter the feasibility study in accordance with local demands.

\footnotetext{
${ }^{142}$ Thurmond, Strom. June $3^{\text {rd }}, 1970$. "Extension of Remarks in the Senate: Education Vouchers," Congressional Record 1970, 18205.

${ }^{143}$ In light of his state's recent past with segregated voucher efforts, this statement is clear in its segregationist implications.

144 Mecklenburger, James. 1972. "Vouchers at Alum Rock". The Phi Delta Kappan. 54 (1), 23.

${ }^{145}$ Weiler, Daniel, and Pierce Barker, A Public School Voucher Demonstration, the First Year at Alum Rock: Prepared for the National Institute of Education (Santa Monica, Ca: Rand, 1974), pp. vi.

${ }^{146}$ Levinson, Eliot, The Alum Rock Voucher Demonstration: Three Years of Implementation (Santa Monica, Calif: Rand Corp, 1976), pp. 7.
} 
Accordingly, a three-month long negotiation between OEO and the school district ensued from January to April of $1972 .{ }^{147}$ Primarily, the school district teachers and principals wanted guaranteed job security, autonomy, and "sufficient resources for innovation."148 Likewise, parents demanded the option to send their children to the local neighborhood school. Conversely, OEO wanted to maintain the more unprecedented elements of its voucher model, those which allowed for a consumer driven education market. Yet due to the lack of interest on behalf of other school districts they had contacted, they were willing to make several concessions on the "free-market" components of the voucher model. Significantly, the local NEA branch, the Alum Rock Educators Association, did not oppose the proposed demonstration. In opposition to the stance taken by the NEA and the California Teachers Association, they remained "officially neutral of the issue, leaving it up to teachers in individual schools to decide if they wished to participate." 149

Arguably, the eventual concessions made by OEO had to do with the controversial nature of Jencks's model. Some local parents joined teachers in uneasiness over the proposal to grant the more power to parents rather than educators, or to offer public funds to private secular schools. As a result, OEO agreed to limit the experiment to only one-third of the schools in the district and to create competition among programs within schools, rather than between the schools themselves. ${ }^{150}$ These concessions led to Alum Rock being labeled as a "transitional" experiment which could eventually transition into a full-fledged voucher program if successful. ${ }^{151}$ This distinction was officially announced by OEO at the end of April 1972 when the revised feasibility study was approved. Specifically, the agreement allowed for only six of

\footnotetext{
${ }^{147}$ Ibid., 7.

${ }^{148}$ Ibid., 7 .

${ }^{149}$ Ibid., 8.

${ }^{150}$ Ibid., 23.

${ }^{151}$ Ibid., 23.
} 
the district's twenty-five schools, and the six which did participate would do so on a volunteer basis. $^{152}$

The initial plan to test a voucher system that included both public and private schools faced further obstacles when in the fall of 1971 the California legislature declined to grant private schools in the district the right to participate. ${ }^{153}$ Yet, the voucher demonstration did allow parents to participate in curriculum development and test smaller sized classes through the minischools. The demonstration also tested the decentralized approach by reducing the power of principals—-seen as Jefferd's secondary reason for partaking in the demonstration—and placing it in the hands of the parents and teachers. ${ }^{154}$ All these attributes fit well within the conservative paradigm of local authority and decentralized decision making.

Soon after OEO's approval of the feasibility study, Alum Rock began to implement what it had already been planning in anticipation of the grant. In order to mobilize information on the experiment and guarantee that parents would make informed decisions, a group of bilingual counselors and their assistants visited parents' homes to outline the proposed demonstration, as well as to advise best possible options for individual children. ${ }^{155}$ At the very least, they would leave brochures for parents with such titles as "What Is a Voucher?" or "Educational Choices for Your Child.",156

Then, abiding by the agenda set forth in the feasibility study, the six schools were organized administratively into twenty-two "mini-schools." The "mini-schools" could loosely be defined as smaller and independent operations within existing institutions designed to provide a more intimate and cooperative learning environment. Indicative of their alternative style, the

\footnotetext{
${ }^{152}$ Ibid., 8.

${ }^{153}$ Ibid., 7.

${ }^{154}$ Ibid., 32.

${ }^{155}$ Mecklenburger, James. 1972. "Vouchers at Alum Rock". The Phi Delta Kappan. 54 (1), 25.

${ }^{156}$ Ibid., 23.
} 
minischools were named according to their objective, "School 2000" and "Three R's Plus" being but two of them. ${ }^{157}$

For the first year alone, $\$ 1,585,800$ was allocated. This was a major improvement in funding for a district whose per-student valuation was under $\$ 6,000$ in a state where the average was $\$ 18,000 .{ }^{158}$ This in large part was a result of per-pupil valuation being tied to residential property values. In fact, property values in the district were so low that during the 1971-72 fiscal year the state had to step in and provide fifty one percent of total funding, far above the state average of thirty three percent. ${ }^{159}$

By the second year, the Alum Rock demonstration expanded from the original six schools to thirteen, going from four to nine thousand students within forty-five minischools. ${ }^{160}$

Moreover, the second year saw the attempt to include a private school. After the district approved the proposal, the institution was contacted for inclusion. Yet, it was not granted autonomy in the negotiations over how the voucher system would work, and parents did not show much interest. In the end, the sign-up rate was too low for the school to open its doors. ${ }^{161}$ Similarly, the third year faced budget concerns after a decline in enrollment. This in turn forced teacher layoffs. ${ }^{162}$

Perhaps in relation of these concerns, reading scores for voucher students actually fell in comparison to scores from earlier years, as well as in comparison to those of pupils from nonvoucher schools. At the same time, the scores from the Metropolitan Achievement Test (MAT) suggested that scores of voucher students increased no more than that of Title I funded

\footnotetext{
${ }^{157}$ Ibid., 25.

${ }^{158}$ Weiler, Daniel and Pierce, Barker., 26.

${ }^{159}$ Ibid., 26.

${ }^{160}$ Levinson, Three Years of Implementation, 16.

${ }^{161}$ Ibid., 16. Of all the sources examined, none specified whether or not this proposed private school was secular or parochial.

${ }^{162}$ Ibid., 17.
} 
students. ${ }^{163}$ In 1976, Robert L. Cain, Rand's Director of Analysis for the voucher project, argued that these low scores "resulted from a misreading of the results." ${ }^{164}$ Even if this were true, Cain was unable to persuade federal officials to prolong the demonstration.

A further indication that Alum Rock failed to achieve its objectives was the lack of participation in the parent advisory committees. Initially set up in each minischool as a venue for parents to actively shape the direction of their respective school, the committees were unproductive from the beginning. Few parents participated on a regular basis, and by the end of 1975 “only 50 percent of minischools' advisory boards were still functioning." 165 By the fourth year, fewer and fewer parents were remembering to enroll their children before the May $30^{\text {th }}$ priority deadline. ${ }^{166}$ These ambiguous results and lack of public support led the authors of the Rand study to the following conclusion as early as 1973:

The major discernible effect of the first year of the demonstration has not been upon parents' behavior or students' academic achievement, but on the roles of central district staff, principals, and teachers. Each voucher school has gained new autonomy, and teachers are now working in new cooperative arrangements and with new discretionary power over resources. It remains to be seen whether the various changes will improve the quality of education and the relationships between citizens and their schools. ${ }^{167}$

Teacher autonomy would be one of the few areas of success for the experiment. Yet this too failed to succeed in the way the feasibility study had initially intended. As Eliot Levinson noted in 1976, the minischools did not create competition among teachers to attract more students, for "they enjoyed working in small groups" and "did not see an advantage in increasing the size of their program."168 Conversely, scholar Jim Warren, also writing in 1976, considered

\footnotetext{
${ }^{163}$ Weiler, Daniel and Pierce, Barker, xxii.

${ }^{164}$ Warren, Jim. 1976. "Alum Rock Voucher Project". Educational Researcher. 5 (3), 14.

${ }^{165}$ Levinson, Three Years, 24.

166 Ibid., 18.

${ }^{167}$ Weiler, Daniel and Pierce, Barker, xxv.

${ }^{168}$ Levinson, Three Years, 25.
} 
this lack of competition a blessing in disguise, for "the teachers seemed to enjoy the smaller class sizes and were not about to rock the boat."169 Unfortunately, creating comfort and security for teachers was not one of the objectives outlined in the feasibility study.

In 1976, Rand conducted another inquiry that would emphasize the lack of impact the demonstration had on test results. The new study concluded that "no appreciable or consistent differences in students' adjusted reading achievement were found between traditional- and alternative-schools," even when grade-level and amount of time in school were accounted for. ${ }^{170}$ In the end Rand found that any change in reading or test levels had to do with teacher selfperception. It concluded "that minischools in which teachers, on average, perceived a cohesive staff, common policies, and some degree of involvement from the principal were associated with higher reading achievement than minischools with teachers perceiving a lack in cohesion, common policies, and principal involvement." ${ }^{171}$ At the same time, "minischools in which teachers, on average, perceived greater autonomy and influence" produced decreasing test scores. ${ }^{172}$ Considering the Director of OEO's testimony before Congress in April 1971 about "the opportunity for individual principals and teachers to be more innovative in the type of curriculum they present," the Rand study seems supportive of the project's aims to improve teacher autonomy, yet it does not seem supportive of its aims to improve student achievement. ${ }^{173}$ Likewise, we see a similar conclusion in a paper delivered by Eliot Levinson at an American Educational Research Association meeting in San Francisco, California, in April of

\footnotetext{
${ }^{169}$ Warren, Jim. 1976. "Alum Rock Voucher Project". Educational Researcher. 5 (3),14.

${ }^{170}$ Capell, Frank J. 1981. A Study of Alternatives in American Education, Vol. VI: Student Outcomes at Alum Rock 1974-1976. Publications Department, The Rand Corporation, 1700 Main Street, Santa Monica, CA 90406, 71.

171 Ibid., 75.

172 Ibid., 75.

${ }^{173}$ Testimony cited in LaNoue, George R., Educational Vouchers; Concepts and Controversies (New York: Teachers College Press, 1972), pp. 152.
} 
1976. "The voucher concept envisioned before the initiation of the Alum Rock experiment," Levinson argued, "was not implemented as planned because it was complex, it was not consonant with the established values of the school system, and it would have radically changed the standard operating procedures and organizational structures that existed prior to the initiation of the demonstration."174

At the same time, not all assessments were negative. Published two months after the East Hartford proposal was rejected, at the beginning of March—-the same month that New Hampshire would reject its own proposed experiment—an article by Jim Warren seemed to cast the project in a more positive light. "Thus far," Warren wrote, "surveys show that the children like it, the parents like it and the teachers love it." ${ }^{175}$ Yet, the author also noted that

The parents generally liked the school system the way it was. They didn't see a crying need for a change. What this seems to mean is that while there is no denying good things appear to be happening in Alum Rock, there is no 'hard' evidence that it would work in another community, like East Hartford, for example. ${ }^{176}$

Scholar John Lindelow expressed similar reservations about vouchers:

When the Alum Rock demonstrations began, parental satisfaction with the public schools was high, and, there were few calls for change. It is not surprising, then, that there was virtually no parental protest when the experiment was terminated in the spring of 1977. The schools now offer about the same programs they did before the experiment, but the district has retained open enrollment and free busing ${ }^{177}$

Undoubtedly, the perceived lack of need for vouchers played a large role in undermining their validity.

\footnotetext{
${ }^{174}$ Levinson, Three Years, 24.

${ }^{175}$ Warren, 13.

${ }^{176}$ Ibid., 15.

${ }^{177}$ Lindelow, John, Educational Vouchers (Reston, Va: National Association of Secondary School Principals, 1979), pp. 26.
} 


\section{Chapter VI: New Hampshire and East Hartford}

You can't try radical untested ideas in the federal government in Washington unless there's some very present danger or some financial emergency or other national kind of emergency to lead you on. A good lesson to learn from vouchers is that democracy really does work; if you don't like vouchers, you're not going to be stuck with them

— Denis Doyle, Division Chief of the School Finance and Organizational Division of $\mathrm{NIE}^{178}$

If we extend the discussion of the efforts of $\mathrm{OEO}$, and later when its operations moved to NIE, following their effort at Alum Rock to the unrealized, yet carefully planned, experiments in the state of New Hampshire and the district of East Hartford, Connecticut, then we again see evidence that parents and teachers failed to see any need for vouchers. Both these experiments were planned in part by NIE to test what had been absent in the Alum Rock experiment: a deregulated experiment which included both private and public schools. Throughout the three-year planning period, NIE was firm in its insistence that these experiments must include these two elements in regions where segregation and exclusion were unlikely to happen. Arguably this decision was also in response to the major concessions OEO made to superintendent Jefferds over the Alum Rock feasibility study. Writing in 1977 after both experiments were voted down, case historians Gordon Donaldson and William Weber argued that "both East Hartford and New Hampshire became the last two hopes for federal voucher proponents to see their ideas for reform translated into action."179

Specifically in the parallel examples of these two planned demonstrations, we see two major factors affecting their failure in the first half of 1976. First, both plans suffered on behalf

\footnotetext{
${ }^{178}$ Donaldson, Gordon A., Education Vouchers in New Hampshire: An Attempt at Free Market Educational Reform. Newton, Mass: C.M. Leinwand Associates, 1977), pp. 46.

${ }^{179}$ Donaldson, Gordon A., and William M. Weber, Vouchers in East Hartford Connecticut and New Hampshire: A Summary. (Newton, Mass: C.M. Leinwand Associates, 1977), pp. 4.
} 
of local confusion. Both residents and educators were dubious from the beginning about the supposed benefits being advocated by voucher officials. We see this in a variety of examplesfrom secular private schools, to teachers' unions, and even to the questions posed by local residents. ${ }^{180}$ Secondly, we see a skeptical attitude on behalf of federal officials at NIE starting in late 1974. This skepticism affected a number of aspects within the two projects, especially concerning budget and the confidence of state-level voucher officials. After NIE made the decision to include the two projects in a category in which only one would eventually receive funding, both faced similar lingering deaths. Neither was able to sustain undivided support from the federal government, nor were they able to obtain approval from their voting constituents. As a result, program organizers at the state level began projecting a doubtful vision, often confusing too, of what a voucher experiment would look like, and any last-ditch efforts to run public awareness campaigns failed to convince the local boards when they voted in the first half of 1976.

Through an examination of the initial enthusiasm on behalf of NIE officials and a subsequent shift to doubt at towards the end of 1974 , as well as the prominent doubts on behalf of local residents and civil servants, one can see how both factors determined the failed outcome of the two experiments, and, again, exemplified the lack of interest for vouchers in the 1970s on behalf of affluent northerners.

\section{New Hampshire}

\footnotetext{
${ }^{180}$ Historian Jim Carl has accounted for this factor in his scholarship concerning the attempted experiment in New Hampshire, yet he omits any discussion of East Hartford. Moreover, he attributes the grassroots efforts of local residents and educators as the predominant reason for the experiment's eventual failure. Arguably, by neglecting to account for East Hartford-an experiment which would become tightly linked to the much larger effort in New Hampshire by NIE officials-he fails to notice the impact that NIE had on both outcomes.
} 
Following Philip V. Sanchez's term as the head of OEO in 1972-73, President Nixon nominated Howard Phillips to the position in January of 1973. Specifically, Nixon emphasized at the time that he chose Phillips so that he could "dismantle" the agency ${ }^{181}$ This objective quickly became a cause for concern among conservative members at $\mathrm{OEO}$ who felt that an unregulated voucher model, and in fact any future voucher projects, might not materialize as a result. ${ }^{182}$ Subsequently, a search for a conservative state government in which a free-market model could be tested began, and OEO officials scurried to contact the state of New Hampshire during the first months of 1973.

In order to understand how federal officials conceived of funding a totally de-regulated experiment encompassing an entire state, one has to first account for their decision to test vouchers far removed from the South, in the northeastern state of New Hampshire. Consisting mostly of white conservatives and an African-American population of 0.3 percent, 1970s New Hampshire was a safe-haven for conservatism, and was not under the legal orders imposed across the South which prohibited vouchers. ${ }^{183}$ Writing one year after the experiment failed, case-historian Gordon Donaldson wrote,

With a conservative Governor of national reputation, a heritage of stubborn Yankee independence, and the distinction of being the only remaining state without an income tax, it seems that New Hampshire presented a likely prospect for an 'unregulated' or 'free-market' version of education vouchers ${ }^{184}$

As this quote indicates, New Hampshire found itself under the leadership of the charismatic conservative Republican governor Meldrim Thomson. Elected governor in 1972 and 1974, he was notorious for running on an "Ax the Tax" platform and supporting apartheid South Africa as

\footnotetext{
${ }^{181}$ Carl, Jim. 2009. "Free Marketeers, Policy Wonks, and Yankee Democracy: School Vouchers in New Hampshire, 1973-1976". Harvard Educational Review. 78 (4): 592.

${ }^{182}$ Donaldson, Gordon New Hampshire, 26

${ }^{183}$ Carl 67, 69

184 Donaldson, Gordon New Hampshire, 26
} 
a supposedly strategic ally; he would prove crucial in sustaining a commitment to neo-

conservative ideologies in subsequent policy discussions between the federal government and the state of New Hampshire. $^{185}$

By April of 1973, the Chairman of New Hampshire's State Board of Education, former businessman William Bittenbender, was unanimous in his support for the experiment and had the approval of the State Board to request funds from OEO by the end of the month. ${ }^{186}$ Furthermore, after turning to Milton Friedman for advice, the Chairman and an economics professor from Dartmouth College, John Menge, drafted and submitted the proposal to Thomson. ${ }^{187}$ Based on the fact that they "unanimously approved 'a voucher test," a funding proposal was then sent to OEO in May. ${ }^{188}$ Soon after, Bittenbender and Menge began to appeal for public support through the local media, announcing that the federal program "might be implemented as early as September of 1973." 189 The project seemed to be off to a promising, yet overly ambitious, start.

The first hindrance to this early sense of enthusiasm came from the federal government. Conservative attitudes were not unanimous among OEO officials in Washington, and as a result, the conservative faction in New Hamsphire, led by Governor Thomson and Bittenbender, was forced to make several concessions on the "unregulated" voucher model to accommodate the opposing faction. Specifically, OEO demanded that the voucher model could not allow "the concentration of low ability, low achieving, or minority children in greater numbers than existed before the test in any participating school," nor the "loss of employment" for "teachers who might have been displaced from their jobs because a school lost students as they took vouchers to

\footnotetext{
${ }^{185}$ Carl 72, Donaldson, Gordon New Hampshire, 12.

${ }^{186}$ Carl, 71 Donaldson, Gordon New Hampshire, 26

${ }^{187}$ Carl, 71.

${ }^{188}$ Donaldson, Gordon New Hampshire, 27.

${ }^{189}$ Ibid., 27.
} 
other schools." 190 OEO also mandated that "no participating school district be allowed to violate Title VI of the Civil Rights Act of 1974."191

A second factor which further hindered the project's early optimism was the sense of fear that emerged in Washington when rumors began to circulate that OEO would close. After his appointment of Phillips in January, the President attempted to impound all appropriated funds for the office. Ironically, this would eventually prove unconstitutional, for the appointment of Phillips as interim director without the approval of Congress was ruled unlawful in a suit filed by Senator Harrison A. Williams through the United States Court of Appeals. ${ }^{192}$ Yet before this was settled, conservative members of the office scrambled to save the proposed project by arranging for any federal responsibility to be shifted to the office of HEW's Assistant Secretary for Planning and Evaluation (ASPE), an office closely related to NIE, for "the top of the HEW hierarchy could, advocates felt, protect the Republican-backed voucher test." ${ }^{193}$ Yet, in spite of this strategic assumption, in August of 1973 both NIE and ASPE rejected the feasibility study over disagreements about the proposed voucher model. ${ }^{194}$ Many officials within these two organizations had a hard time going against the compensatory model outlined by Jencks in his 1969 report. $^{195}$

As Jim Carl has pointed out, the proposal faced an additional "setback when the U.S. Supreme Court handed down two decisions that essentially ended programs of state tax support

\footnotetext{
${ }^{190}$ Ibid., 14-15.

${ }^{191}$ Ibid., 14.

192 Senator Harrison A. WILLIAMS, Jr. et al.v.Howard J. PHILLIPS, Acting Director, Office of Economic Opportunity, Appellant. United States Court of Appeals, District of Columbia Circuit.(Argued June 21, 1973.Decided June 22, 1973).

${ }^{193}$ Donaldson, Gordon New Hampshire, 27.

${ }^{194}$ Ibid., 28.

${ }^{195}$ Ibid., 29.
} 
for tuition at religious elementary and secondary schools." ${ }^{196}$ Specifically, in Sloan v. Lemon and Committee for Public Education and Religious Liberty v. Nyquist (1973), the Supreme Court declared that "tuition reimbursements for parents and tuition grants for students enrolled in sectarian schools were unconstitutional." ${ }^{, 197}$ As a result of these rulings, the federal government mandated that New Hampshire produce a revised feasibility study, which would exclude religious institutions. ${ }^{198}$ This decision further delayed the drafting of the revised feasibility study by Menge and the Director of CSPP. Belatedly in November of 1973, the study was accepted by the State Board. ${ }^{199}$

Feeling confident about the third feasibility study, the Chairman and various public officials began planning the project and contacting state districts for participation support. Despite Bittenbender's efforts, though, a number of voices within the state began to speak out when they were informed of the proposed experiment. This response in large part derived from negative local news articles, and consequently, a number of public meetings were held throughout the state in order to address both sides of the voucher debate with officials present. Many of these meetings left citizens confused over how the experiment would work. ${ }^{200}$

Fueling this confusion and doubt, several local groups emerged in opposition to the proposed experiment. Among the most vocal opponents was the New Hampshire Education Association, the state affiliate of the NEA. With vigor, members travelled to school districts, arguing that a "pure voucher would make schools socio-economically homogeneous, permit the rise of substandard institutions, and lead to the decline of public education."201 More pointedly,

\footnotetext{
${ }^{196}$ Carl, 73.

${ }^{197}$ Ibid., 73. Committee for Public Ed. \& Religious Liberty v. Nyquist, 413 US 756 - Supreme Court 1973.

${ }^{198}$ Ibid., 73.

${ }^{199}$ Donaldson, Gordon New Hampshire, 29.

${ }^{200}$ Ibid., 31.

201 Ibid., 31.
} 
the organizational leaders wrote columns in local and national newspapers, which at times veered towards racist and class based imagery. Referring to Alum Rock, the local branch NEA Director of Professional Development noted that "forty percent of families . . . are supplemented by welfare funds," and that course offerings there included "multicultural field trips" including "soul-food dinners and luau celebrations." ${ }^{202}$ Meanwhile, the small amount of support for the experiment mainly came from established organizations and citizens' groups such as the Roman Catholic Archdiocese of Manchester; although, the archdiocese's support faded after the Supreme Court decision. ${ }^{203}$

In spite of criticism, officials in New Hampshire continued their efforts, and by January of the following year, an office titled the "Education Voucher Project" had been established in the State Department of Education. Additionally, by June of 1974, seven communities had signed up to participate in the experiment. ${ }^{204}$ Based on of the approval of the feasibility study, a planning proposal was submitted that "established September 1975 as the beginning of an operational unregulated voucher program." ${ }^{205}$ Significantly, though, the seven districts which signed on to participate were out of the initial thirty-one districts approached in April of $1974,{ }^{206}$ and officials were dissatisfied by this low number and quick to coordinate a new effort to involve a total of 6,000 students. ${ }^{207}$ This was not solely to meet federal research guidelines. Instead, it can be seen as a desperate attempt to heighten the validity of the experiment, as well as to bring in the larger districts of Salem, Berlin, and Nashua. Yet, when Berlin and Nashua opted not to join the program, the proposed 6,000 no longer seemed realistic, as did the proposed July

\footnotetext{
${ }^{202}$ Carl, 78.

${ }^{203}$ Donaldson, New Hampshire, 31.

${ }^{204}$ Ibid., 5.

205 Ibid., 5.

${ }^{206}$ Ibid., 31.

${ }^{207}$ Ibid., 32.
} 
beginning of the experiment. ${ }^{208}$ As a further and even more dramatic blow, the director of the Voucher Office resigned in mid-May over internal disagreements. ${ }^{209}$

This early opposition on behalf of local communities would soon be coupled by a much larger obstacle presented by NIE. ${ }^{210}$ Perhaps in light of a sense of doubt expressed by Congress about the proposed demonstration, NIE too began to question the voucher test. ${ }^{211}$ At the very least, it questioned whether or not vouchers were a viable alternative source of funding. This came in part because of the recent results at Alum Rock, but more so, it came from NIE's dire budget situation. ${ }^{212}$ Broadly speaking, the early 1970 s witnessed an utter lack of consistency in terms of budgeting at NIE. When NIE's annual budget was reduced from $\$ 130$ million to $\$ 70$ million, in one year, Congressional leaders like Edith Green of Oregon suggested that their appropriation should be slashed entirely. ${ }^{213}$ In response, all that Denge and Thomson could muster was a trip to Capitol Hill to lobby for NIE and vouchers. ${ }^{214}$

At this point, in December of 1974 when the project momentum began to stagnate, the voucher staff at NIE decided it might be worthwhile to combine their efforts in New Hampshire with their other experiment being planned for East Hartford, Connecticut. As a result of this compromise, the budget Congress approved in January of 1975 permitted funding for a voucher experiment. Although allowing the New Hampshire test to be funded for a fifteen month term,

${ }^{208}$ Ibid., 31

${ }^{209}$ Ibid., 32.

${ }^{210}$ Jim Carl, being one of the few historians to write on the New Hampshire experiment, suggests that Berlin and Nashua were the primary cause for the experiments ultimate failure. Due to the populist movements which emerged in these districts, Carl argues, the opinions became too oppositional and in turn any sort of compromise failed. In his historical analysis published in 2012, therefore, he concludes that the experiment would dwindle away from there and teach future voucher policy advocates important lessons to avoid. While this does account for a major factor, demographic consensus, it nevertheless fails to address the pressures exerted by NIE when the organization began to face Congressional pressure to decrease its funding for vouchers. This Congressional pressure would inevitably distract the officials attempting to facilitate the program experiment in New Hampshire, and therefore, can be seen as the longterm trend which undermined the possibility for an experiment.

211 Ibid., 34.

212 Ibid., 34

${ }^{213}$ Ibid., 32.

${ }^{214}$ Ibid., 34. 
however, it was "split funded" with the East Hartford budget under the stipulation that one of the two might eventually be fully-funded. ${ }^{215}$ This decision to essentially attach the two projects and make them dependent on one another began in the late fall of 1974. Yet, significantly, the two sites failed to make any major contact with one another over the course of the following year. ${ }^{216}$ This failure to communicate would in turn promote the fear of the East Hartford planners that they might not get any money in the case that New Hampshire voted to implement its proposal. $^{217}$

In the site-history commissioned by NIE on East Hartford, Gordon Donaldson argued that "the simultaneous development of the New Hampshire voucher project had kept the Connecticut site's funding hopes alive," for by the end of 1974, "NIE staff believed that if East Hartford were to receive any money, it would have to be linked to New Hampshire."218 This in large part had to do with the power New Hampshire held in the eyes of staffers. ${ }^{219}$ One year later, however, Donaldson would argue that "the delay had frustrated all New Hampshire personnel, undercut the momentum" of the spring of $1974 .^{220}$

In spite of this lack of enthusiasm and doubt over federal finances, Menge, Thomson, the state commissioner of education Newell Paire, Bittenbender, and NIE decided to continue their efforts. $^{221}$ Ultimately, though, New Hampshire was unable to sustain support after NIE faltered on its commitment to the program.

\footnotetext{
${ }^{215}$ Ibid., 35.

${ }^{216}$ Weber, William M. 1977. History of education vouchers in East Hartford Connecticut: the Parent's Choice Project : February 1975 - January 1976. Newton, Mass: C.M. Leinwand Associates, 35.

${ }^{217}$ Ibid., 34.

${ }^{218}$ Ibid., 33.

219 'It was New Hampshire which had political ties to the White House through State Board of Education Chairman William Bittenbender who in turn brought political leverage to the NIE budget." Donaldson, New Hampshire, 35.

${ }^{220}$ Ibid., 35.

221 Ibid., 33.
} 


\section{East Hartford}

In 1972, the Center for the Study of Public Policy (CSPP) helped pass Public Act 122 in the Connecticut legislature, which "encouraged participation of private schools in voucher-type programs" throughout the district. ${ }^{222}$ Strategically, the center subtly advised the legislature to pass the bill to make way for a federal test of vouchers. Despite an initial lack of enthusiasm, CSPP persisted in its advocacy for vouchers, and in 1973 hosted a workshop at the Connecticut Association of Boards of Education on the experiment at Alum Rock. In attendance were the East Hartford Public School Superintendent Eugene Diggs and the Board of Education Chairman Timothy Monahan. ${ }^{223}$

As was the case with Governor Thomson in New Hampshire, the early efforts in East Hartford largely depended on Diggs's commitment to the concept. The public school superintendent was a powerful figure in the short trajectory of vouchers in East Hartford, yet unlike Thomson, Diggs did not uphold a right-wing ideology. ${ }^{224}$ Rather, he placed most of his energies behind the potential of experimentation of alternative forms of education and alternative forms of funding for the sake of improving the quality of education. ${ }^{225}$ Therefore, when he heard the report on vouchers at the annual board meeting, he reportedly told Monahan that "there's nothing that they (Alum Rock) are doing right now which we couldn't do, except provide money for transportation and administrative training.,226

Soon after the workshop, Diggs was in contact with NIE, and following a series of successful negotiations, out of which Diggs was granted a significant amount of leeway on how

\footnotetext{
${ }^{222}$ Weber, East Hartford, 20.

${ }^{223}$ Ibid., 20.

${ }^{224}$ Ibid., 20.

${ }^{225}$ Ibid., 14. One of his earlier experiments involved the testing of year-round academic terms-an experiment which yielded few quantitative results, yet nevertheless failed to deter him from further experimentation ${ }^{226}$ Ibid., 20.
} 
the project could work, the East Hartford Board of Education gave him "the authority to plan such a study" in December 1973. In the first week of 1974, NIE received a formal proposal. ${ }^{227}$ Reflecting its optimistic attitude, NIE officials granted East Hartford $\$ 69,000$ to produce a feasibility study only two weeks after the state had submitted a formal proposal. In mid-April, the three-month long process of drafting the study was complete. Perhaps in light of the overly eager attitude exhibited by NIE and the education officials in East Hartford, "A Feasibility Analysis of Open Enrollment, East Hartford, Connecticut, January 21, 1974 to April 21, 1974” boldly began with a call for a new form of education in "response to latter twentieth century individuals rather than to the earlier mold" of education found in the first half of the century. ${ }^{228}$

At the same time, the study also argued "that more work had to be done if East Hartford were to go ahead in adopting a voucher program.."229 Unfortunately, this additional work would require more funds from NIE right at the time when the institute was unable to pass a budget through Congress. Several months would pass before a revised proposal, under the new name of "Parents' Choice," was approved by NIE and finally allowed to go into effect in February $1975 .^{230}$

Similar to New Hampshire, the delay due to NIE's budget concerns would undermine the program's potential alongside a lack of public support. In order to understand this lack of public backing, one must account for the fact that East Hartford, too, was largely homogenous in its demographic make-up. According to the 1970 census, the annual median income was reported at

\footnotetext{
${ }^{227}$ Ibid., 21

${ }^{228}$ East Hartford Board of Education, CT. 1974. A Feasibility Analysis of Open Enrollment: East Hartford, Connecticut, January 21, 1974 to April 21, 1974, i-ii.

${ }^{229}$ Weber, East Hartford, 18.

${ }^{230}$ Ibid., 18
} 
$\$ 12,000$, and “over 98 percent of East Hartford's 57,000-plus population was white."231 On top of this, roughly fifty percent of the population was Catholic. ${ }^{232}$

As was the case when they discovered similar information about New Hampshire, NIE officials were pleased to avoid any potential problems due to racial segregation. Equally appealing to the officials at NIE was the call within the proposal for the inclusion of private schools—-both parochial and secular. This was in large part the result of the declining interest in East Hartford parochial schools at the time. Education officials in the state were already anticipating an influx of Catholic school students to the public schools, with absorptions of more than two-hundred students from Catholic institutions at a time. ${ }^{233}$ Thus, public officials already felt that they had a "private school issue" which needed to be fixed. Moreover, in spite of the recent Supreme Court decision against federal funds going towards religious private schools, NIE felt more confident about East Hartford due to Public Act 122 which enabled public school districts and private schools "to participate in a demonstration program designed to develop and test the use of Education Scholarships for schoolchildren. ${ }^{234}$

East Hartford planners were convinced parochial schools would be allowed to participate based on a footnote found in Committee for Public Education and Religious Liberty et. al. v. Nyquist which suggested that "some form of public assistance (e.g., scholarships) made available generally without regard to the sectarian-nonsectarian, or public-nonpublic nature of the institution benefited" might not "impermissibly advance religion in violation of the

\footnotetext{
${ }^{231}$ Ibid., 17.

232 Ibid., 49.

${ }^{233}$ Ibid., 49.

${ }^{234}$ East Hartford Board of Education, CT. 1974. A Feasibility Analysis of Open Enrollment: East Hartford, Connecticut, January 21, 1974 to April 21, 1974, 234.
} 
Establishment Cause."235 East Hartford and NIE felt that they could sustain parochial involvement through the law which used the word scholarship, as opposed to voucher.

Accordingly, a local Catholic Priest and the Superintendent of the Catholic schools in Hartford, Father James Fanelli, began mobilizing support among his parish and local community through the rhetoric of Father Virgil Blum. Emphasizing "Freedom of Choice," Fanelli began to distribute a pamphlet newsletter with the headline "Would you be interested if someone offered you a check to pay for your child's tuition?"236 Yet, later that summer when two local Catholic schools voted on whether or not to support any further voucher discussion, the results were mixed, with one school supporting the idea and the other opposing it. ${ }^{237}$ St. Christopher Middle School opposed the project so long as officials remained vague about how it would unfold and affect teaching and administration; while St. Rose Middle School was supportive of the idea because they felt it "would benefit Catholic schools, children, and parents."238

In concern over how the Supreme Court might respond to the inclusion of parochial schools, the district also sought to include secular private schools. ${ }^{239}$ Of the secular private academies contacted, the interest on behalf of a local Montessori school seemed the most promising. Ultimately, though, the school exemplified the inadequacy of vouchers to fit the needs of pre-existing alternative schools.

In October of 1975, the administrator of the Montessori School of Greater Hartford, Mary Daly, eagerly requested to receive more information about the Parents' Choice program in case she wanted to involve her school in the project. ${ }^{240}$ Previously, Daly had been told about the

\footnotetext{
${ }^{235}$ Committee for Public Education and Religious Liberty et. al. v. Nyquist (1973) footnote 38; Weber, East Hartford, 50.

${ }^{236}$ Weber, East Hartford, 49.

${ }^{237}$ Ibid., 53.

${ }^{238}$ Ibid., 62.

${ }^{239}$ Ibid., 49.

${ }^{240}$ Ibid., 41.
} 
potential for vouchers at her school by Father Fanelli, and, similar to Dr. Jefferds at Alum Rock, was primarily interested as a result of potential funding to "secure a larger and more stable site" for their school. ${ }^{241}$ However, at a meeting held at the end of October in response to Daly's request for more information, it quickly became apparent that it would be quite difficult to accommodate a private school like Montessori in a program which depended upon equal, uniform standards on behalf of all participating schools.

Specific obstacles presented themselves in relation to curriculum and, more importantly, in terms of starting the age at Montessori. At Montessori School of Greater Hartford, a typical student began attending at the age of three, whereas public school students started in kindergarten at the age of five. Moreover, Montessori academies had distinct education methods which did not depend on age-segregated grade levels. Understandably, this often confused public school administrators, as well interested parents. ${ }^{242}$ Through subsequent discussion concerning budget solutions to accommodate the alternative curriculum, the Montessori school, along with several other public schools who considered vouchers, decided not to participate because of these reasons in late November. ${ }^{243}$

By the spring of 1975, a distinctly incoherent and disjointed reaction on behalf of the East Hartford community emerged, and a variety of organizations began to lash out at the proposed experiment. The League of Women Voters argued that they did not "know what Parents' Choice or the vouchers are all about."244 The NEA, as usual, officially opposed any form of vouchers, claiming that "voucher plans under which education is financed by federal or state grants to parents could lead to racial, economic, and social isolation of children or destroy the public

\footnotetext{
${ }^{241}$ Ibid., 41.

${ }^{242}$ Ibid., 42.

${ }^{243}$ Ibid., 48.

${ }^{244}$ Ibid., 90.
} 
school system." The organization now called for the "enactment of federal and state legislation prohibiting voucher feasibility studies and the establishment of voucher plans."245 Meanwhile, many local residents worried about turning public schools into a "last resort."246 Like New Hampshire, this came as a result of the "informed consent" section in the feasibility study, which was created "to insure that parents of students enrolled in the East Hartford Public Schools are fully informed and understand the various educational options" before it became operational. ${ }^{247}$ In response, the staff for the Parents' Choice project felt the majority of criticisms came from a lack of understanding. As one staffer argued,

The majority of people in East Hartford may have somewhat negative feelings toward the project, but given adequate information, many of them would change their opinions, Because most of the critical questions I heard addressed to the project really don't stand up - - they are a kind of anxiety question - - questions coming out of not understanding. I don't hear any real questions in terms of hard issues. The teachers wanting to know how this is going to perhaps jeopardize their jobs. When in reality this is probably not going to do that. Or it's parents wanting to know if this is going to mean children coming from Hartford to East Hartford, which this is not going to do. These are questions that I feel can be answered and should be answered, and therefore, people will support the project when given those answers, or will be more likely to support it. $^{248}$

Elsewhere, however, even local Connecticut principals were opposed to the voucher proposal, voting unanimously, 18-0, against vouchers in January of $1976 .^{249}$

Meanwhile, the budget uncertainties concerning NIE lingered on and continued to cause headaches for administrators in Connecticut—similar to the simultaneous situation in New Hampshire. In mid-May 1975, after NIE had failed to release the funds for six months, Diggs made the following formal request to NIE:

\footnotetext{
${ }^{245}$ Ibid., 95

246 Ibid., 98, 90

${ }^{247}$ East Hartford Board of Education, CT. 1974. A Feasibility Analysis of Open Enrollment: East Hartford, Connecticut, January 21, 1974 to April 21, 1974," 32

${ }^{248}$ Weber, East Hartford, 90.

${ }^{249}$ Ibid., 110.
} 
I wish to move ahead ... Program changes for which we are now planning could be profoundly valuable to the children in our schools. I respectfully request at the [HEW] Secretary's earliest convenience assurances that our planning will not be futile $!^{250}$

Yet, this along with Diggs's many other demands could not be guaranteed-in part because NIE was required to submit a budget for approval to Congress on an annual basis and, accordingly, could not make any long-term commitments. ${ }^{251}$ Similar to New Hampshire, the combination of local opposition and doubts about NIE would undermine any initial enthusiasm.

${ }^{250}$ Ibid., 33

${ }^{251}$ Ibid., 33 


\section{Chapter VII: Conclusion - Milwaukee, Wisconsin}

The steam has gone out of it, the federal government just doesn't seem to care about it

-Denis Doyle, Division Chief of the School Finance and Organizational Division of NIE, $1976^{252}$

By August of 1975, NIE still did not have the money available to fund both projects. This caused Diggs to conclude that "the NIE budget seemed increasingly less likely to include funds to support an East Hartford voucher project." ${ }^{, 253}$ Even after a major effort to force the release of NIE funds occurred at a budget strategy session arranged in connection with CSPP in midAugust, in which letters were sent to U.S. Senators and the Chairman of the New Hampshire Board of Education, William Bittenbender, East Hartford was still left empty handed. ${ }^{254}$

Furthermore, HEW began to waver on its support as a result of a new secretary, and a lack of communication between the agency and NIE proved equally crippling. ${ }^{255}$ As Donaldson's casehistory indicates, by mid-January of 1976, "it appeared that little could be done by voucher advocates or critics to fundamentally shift public opinion in any substantial way." ${ }^{256}$ Reflecting this sentiment, on January 26, 1976, a vote was held by the East Hartford Board of Education on whether or not to apply for "federal funds to actually implement a voucher program." The final tally was a decisive six to two against any continued funding, and the project subsequently ended. ${ }^{257}$ Likewise, after an arduous final eighteen months in which New Hampshire's local

\footnotetext{
${ }^{252}$ Warren, Jim. 1976. "Alum Rock Voucher Project". Educational Researcher. 5 (3), 15

${ }^{253}$ Weber, East Hartford, 34.

${ }^{254}$ Ibid., 34.

${ }^{255}$ Ibid., 41.

${ }^{256}$ Donaldson, New Hampshire, 114.

${ }^{257}$ Donaldson, Gordon A., and William M. Weber. 1977. Vouchers in East Hartford Connecticut and New Hampshire: a summary. Newton, Mass: C.M. Leinwand Associates, 5.
} 
distrust was perpetuated by federal doubt, all six remaining districts voted not to participate in February and March of $1976 .^{258}$

Arguably, Alum Rock had been blessed with a confident Congress which dared to grant funding, albeit still reluctantly, for an untested concept in 1972. Given that Congressional leaders had the opportunity to observe the failures at Alum Rock while they were being lobbied by New Hampshire and Connecticut officials in 1975 to increase NIE's voucher funds, one can understand why the heightened reluctance was so strong. Separating these three experiments from one another does not do any of them justice, for when combined they show that distinct variations of voucher models were tested — either in hypothetical or in actual form—based in part on what the other experiments were achieving.

Likewise, each of these three experiments were in some degree shaped by the racist legacy of vouchers exemplified by such cases as Prince Edward County. The illegal and unfruitful results that the experiments on behalf of segregation advocates in states like Virginia produced helps to explain why the Alum Rock experiment was so tightly regulated, and why it is in turn seen as a failure by voucher advocates from the 1980s onward—often entirely omitted from policy proposals. ${ }^{259}$ In reaction to the pitfalls of allowing unregulated use of vouchers, the experiment at Alum Rock was purposefully regulated. Nearly all subsequent voucher experiments and proposals, however, have been deregulated.

The question, therefore, becomes what significance the demonstrations of the early 1970s had on future discussion surrounding vouchers and alternative, more conservative, forms of

\footnotetext{
${ }^{258}$ Donaldson, New Hamsphire, 34.

${ }^{259}$ It seems that once the 1980s rolled around many policy advocates chose to omit the southern segregationist episodes altogether. Likewise, the discussion of Alum Rock became minimized as an inadequate test., or in particular cases, exploited as a more efficient and effective experiment than it actually was. An example of such a text is Kirkpatrick, David W. 1990. Choice in schooling: a case for tuition vouchers. Chicago: Loyola University Press. Crucially, he fails to note the RAND studies in his discussion.
} 
education not dependent on Title I funding. For starters, after the demonstration at Alum Rock concluded in the fall of 1976-less than six months after the proposed East Hartford and New Hampshire experiments were voted down —it remained the only demonstration of vouchers until Milwaukee, Wisconsin, began its own program in 1990.

After the resignation of President Nixon in 1974, therefore, calls for vouchers at the federal level remained absent until 1980, and even then, advocacy was scant. One can argue that the Watergate scandal did in fact have an impact on federal priorities concerning education, as the NIE slowdown began in August of 1974. Later, as president, Ronald Reagan often called for them—specific proposals were made to the $98^{\text {th }}$ and $99^{\text {th }}$ Congress to enact voucher programsbut no official demonstration was funded while he was in office. ${ }^{260}$ It seems that the results produced by Alum Rock were neither promising nor noteworthy in the eyes of legislators and policy researchers. When the Rand study concluded that "the students in regular schools consistently outperformed students in alternative schools," it becomes easy to see why. ${ }^{261}$

Beginning in the 1990s, the Milwaukee Parental Choice Program's successful implementation was not a result of federal initiatives. Rather, the voucher program came from the cooperation between a conservative Republican governor, Tommy Thomson, and a liberal state representative, Annette Williams. ${ }^{262}$ Based on a growing dissatisfaction with urban, predominantly minority populated schools, the black community lobbied relentlessly behind Williams to end the continued segregation in the Milwaukee metropolitan area ${ }^{263}$ The initial bill did not allow for parochial schools to participate, but this was later granted in $1995 .{ }^{264}$

\footnotetext{
${ }^{260}$ Kirkpatrick, David W., Choice in Schooling: A Case for Tuition Vouchers. (Chicago: Loyola University Press, 1990), 4.

${ }^{261}$ Ibid., 27.

${ }^{262}$ Carl, 84

${ }^{263}$ Ibid., 100

${ }^{264}$ Ibid., 101
} 
Subsequently, impoverished minorities began attending local Catholic schools in droves. The program continues to this day, and it has since inspired a wave of similar programs in the North and the South.

At its heart, vouchers were supposed to change the structure through which students received education. Through this change of structure and environment, an improvement in learning was supposed to come about naturally. Instead of increased funding to improve services and education quality, vouchers were meant to redefine the way parents, educators, and students approached education without dependence on additional financial support. Yet conservatives of the 1970s still operated within the shadow of Great Society institutions like the Office of Economic Opportunity and later the National Institute of Education and were far too conscience of the beneficial components of the ESEA to bypass all of its categorical funding. Despite Nixon's criticisms, many school administrators remained loyal to the legislative programs presented by the ESEA, arguably because of the funding it brought to their districts.

Great Society historians are wont to point out how the LBJ's social welfare program differed from the New Deal thirty years earlier. While the New Deal was implemented to rescue an unemployed and impoverished workforce from the depths of a depression, the Great Society was meant to give back to those citizens who had not benefited from the post-war boom, or "affluent society," and help out those who were marginalized in society—namely, the impoverished and racial minorities. ${ }^{265}$ According to these definitions, vouchers fit well within the Great Society ideology—albeit as long as they maintained regulations guaranteeing racial and class equality. Vouchers were meant to improve an already "thriving" education system in affluent places like New Hampshire and East Hartford, while improving the situation of the

\footnotetext{
${ }^{265}$ Unger, Irwin, The Best of Intentions: the Triumphs and Failures of the Great Society Under Kennedy, Johnson, and Nixon (New York: Doubleday, 1996).
} 
impoverished in places like Alum Rock. Accordingly, they can be seen as an appropriate ideology, a proposal, which was ultimately deemed unnecessary at the time. The only demographic among which it found widespread support—if only briefly—was among a deeply impoverished community in Alum Rock, yet this too was ultimately a failure due to its incapacity to persuade parents that vouchers were indeed a superior alternative.

In current policy discussions, vouchers are seen more in line with how social welfare programs were seen during the 1930s. Neo-liberals and evangelicals in the South in the first decade of the twenty-first century are eager to use vouchers to escape curricula that they disagree with on a moral and philosophical basis, while inner-city minorities are desperate to use them as a financial means to escape to private schools. They were passed in order to solve a dire problem, not create an alternative possibility. No longer are vouchers seen as the "revolutionary" alternative they were labeled as in the early 1970s.

Thus, in the 1970s, policy advocates were being idealistic about the potential for vouchers to debunk the Elementary and Secondary Education Act. By 1973, Title I programs were receiving $\$ 1.3$ billion annually. ${ }^{266}$ Once districts became accustomed to receiving these vast federal funds, it became hard for Congress or the White House to take them away. Most alternatives seemed irrelevant, and the inability of conservatives to produce a functional alternative, untarnished by a segregationist past, hindered this effort even moreso. Observing that George W. Bush's reauthorization of the bill in 2001 passed the House of Representatives by a vote of 384 to forty-five and the Senate ninety-one to eight, only exemplifies this further. ${ }^{267} 268$

\footnotetext{
${ }^{266}$ Ibid., 336.

${ }^{267}$ FINAL VOTE RESULTS FOR ROLL CALL 145. (2001, May 23). Retrieved from Clerk.House.Gov website: http://clerk.house.gov/evs/2001/roll145.xml;

${ }^{268}$ U.S. Senate Roll Call Votes 107th Congress - 1st Session H.R. 1 (No Child Left Behind Act of 2001 ). (2001, June 14). Retrieved from United States Senate website: http://www.senate.gov/legislative/LIS/roll_call_lists/roll_call_vote_cfm.cfm?congress=107\&session=1\&vo te $=00192$
} 
Thus throughout the 1970s, conservatives, like liberals, decided to let it be, refusing to fund it at times, but always acknowledging that the ESEA would be a legislative mainstay. 


\section{Bibliography}

Allen Jr., James, “An Interview with James Allen,” Harvard Educational Review (Cambridge, Mass: Harvard University, Winter 1970), pp. 533-546.

Almond v. Day, 197 Va. 419, 89 S. E 2d 851, 1955.

Bailey, Stephen Kemp, and Edith K. Mosher, ESEA; The Office of Education Administers a Law (Syracuse, N.Y.: Syracuse University Press, 1968).

Bernstein, Irving, Guns or Butter: the Presidency of Lyndon Johnson (New York: Oxford University Press, 1996).

Bernstein, Irving, Promises kept: John F. Kennedy's New Frontier (New York: Oxford University Press, 1991).

Blum, Virgil C. Freedom of Choice in Education (New York: Macmillan, 1958).

Bonastia, Christopher, Southern Stalemate: Five Years Without Public Education in Prince Edward County, Virginia (Chicago: The University of Chicago Press, 2012).

Brown v. Board of Education, 349 US 294, 75 S. Ct. 753, 99 L. Ed. 1083 - Supreme Court, 1955.

Capell, Frank J, A Study of Alternatives in American Education, Vol. VI: Student Outcomes at Alum Rock 1974-1976 (Publications Department, The Rand Corporation, 1700 Main Street, Santa Monica, CA 90406, 1981).

Carl, Jim, Freedom of Choice: Vouchers in American Education (Santa Barbara, Calif: Praeger, 2011).

Carl, Jim. 2009, "Free Marketeers, Policy Wonks, and Yankee Democracy: School Vouchers in New Hampshire, 1973-1976" (Harvard Educational Review. 78 [4], 2009), 589-614. 
Daugherity, Brian J., and Charles C. Bolton, With all Deliberate Speed: Implementing Brown v. Board of Education (Fayetteville: University of Arkansas Press, 2008).

Davies, Gareth, "Towards Big-Government Conservatism: Conservatives and Federal Aid to Education in the 1970s" (Journal of Contemporary History. 43 [4], 2002), 621-635.

Davies, Gareth, "The Great Society after Johnson: The Case of Bilingual Education" (The Journal of American History. 88 [4], 2002), 1405-1429.

Divine, Robert A., Exploring the Johnson Years (Austin, Tex: University of Texas Press, 1981). Donaldson, Gordon A., Education Vouchers in New Hampshire: An Attempt at Free Market Educational Reform (Newton, Mass: C.M. Leinwand Associates, 1977).

Donaldson, Gordon A., and William M. Weber, Vouchers in East Hartford Connecticut and New Hampshire: A Summary. Newton, Mass: C.M. Leinwand Associates, 1977).

Finn, Chester E., Education and the Presidency (Lexington, Mass: Lexington Books, 1977).

Friedman, Milton, "Economic policy \& social control: Role of government in education" in Solo, Robert A. Economics and the public interest. [Essays written in honor of Eugene Ewald Agger] (New Brunswick, N.J.: Rutgers University Press, 1955).

Graham, Hugh Davis, The Uncertain Triumph: Federal Education Policy in the Kennedy and Johnson Years (Chapel Hill: University of North Carolina Press, 1984).

Graham, Hugh Davis, and Nancy Diamond, The Rise of American Research Universities: Elites and Challengers in the Postwar Era (Baltimore, Md: Johns Hopkins University Press, 1997).

Gray, Garland, Public Education Report of the Commission to the Governor of Virginia (Commonwealth of Virginia Division of Purchase and Printing Richmond, 1955).

Griffin Et Al. v. County School Board of Prince Edward County, 377 U.S. 218 (1964). 
Griffin v. State Board of Education, 296 F. Supp. 1178-Dist. (1969).

Hicks, Terence, and Abul Pitre, The Educational Lockout of African Americans in Prince Edward County, Virginia (1959-1964): Personal Accounts and Reflections (Lanham, Md: University Press of America, 2010).

Jeffrey, Julie Roy, Education for Children of the Poor: A Study of the Origins and Implementation of the Elementary and Secondary Education Act of 1965 (Columbus: Ohio State University Press, 1977).

Kessinger, T. A., "Efforts Towards Educational Reform in the United States Since 1958" (American Educational Historical Journal, Vol. 38, No. 1/2, 2011), pp. 263-276.

Kirkpatrick, David W., Choice in Schooling: A Case for Tuition Vouchers (Chicago: Loyola University Press, 1990).

La Noue, George R., Educational Vouchers; Concepts and Controversies (New York: Teachers College Press, 1972)

Leuchtenburg, William E, “The Genesis of the Great Society,” (The Reporter, April 21, 1966) pp. 36-39.

Mecklenburger, James, "Vouchers at Alum Rock" (The Phi Delta Kappan. 54 [1], 1972), pp. 2325.

Meranto, Philip, The Politics of Federal Aid to Education in 1965; A Study in Political Innovation (Syracuse, N.Y.: Syracuse University Press, 1967).

Milkis, Sidney M., and Jerome M. Mileur, The Great Society and the High Tide of Liberalism (Amherst: University of Massachusetts Press, 2005).

Perrow, Mosby G., Report of the Commission on Education to the Commonwealth of Virginia (Division of Purchase and Printing Richmond, 1955). 
Ravitch, Diane, The troubled crusade: American education, 1945-1980 (New York: Basic Books, 1983).

Sanchez, Ramon, "John Dewey's the School and Society. Perspectives 1969," (History of Education Quarterly, Vol. 10 No. 1, 1970), pp. 78-83.

Titus, Jill Ogline, Brown's Battleground: Students, Segregationists, and the Struggle for Justice in Prince Edward County, Virginia (Chapel Hill: University of North Carolina Press, 2011).

Unger, Irwin, The Best of Intentions: The Triumphs and Failures of the Great Society Under Kennedy, Johnson, and Nixon (New York: Doubleday, 1996).

Warren, Jim, "Alum Rock Voucher Project" (Educational Researcher. 5 [3], 1976), pp. 13-15.

Weber, William M., History of Education Vouchers in East Hartford Connecticut: the Parent's Choice Project: February 1975 - January 1976 (Newton, Mass: C.M. Leinwand Associates, 1977)

Weiler, Daniel, and Pierce Barker, A Public School Voucher Demonstration, the First Year at Alum Rock: Prepared for the National Institute of Education. (Santa Monica, Ca: Rand, 1974). 